\title{
Director networks and informed traders ${ }^{\text {t }}$
}

\author{
Ferhat Akbas $^{\mathrm{a}}$, Felix Meschke ${ }^{\mathrm{a}}$, M. Babajide Wintoki ${ }^{\mathrm{a}}$ \\ ${ }^{a}$ School of Business, University of Kansas, Lawrence, KS 66045, USA
}

\begin{abstract}
We provide evidence that sophisticated investors like short sellers, option traders, and financial institutions are more informed when trading stocks of companies with more connected board members. For firms with large director networks, the annualized return difference between the highest and lowest quintile of informed trading ranges from $4 \%$ to $7.2 \%$ compared to the same return difference in firms with less connected directors. Sophisticated investors better predict outcomes of upcoming earnings surprises and firm-specific news sentiment for companies with more connected directors. Changes in board connectedness are positively associated with changes in measures of adverse selection.
\end{abstract}

\footnotetext{
${ }^{\star}$ We would like to thank Raj Agrawal, Chris Anderson, Bill Beedles, Ekkehart Boehmer, David Cicero, Sevinc Cukurova, Bob DeYoung, Brad Goldie, Ying Huang, Kissan Joseph, Paul Koch, Lei Li, Jacob Oded, and seminar participants at the University of Kansas, Iowa State University, University of South Florida, the 2014 Financial Management Association (FMA) Annual Meeting, the 2014 Jerusalem Finance Conference, the 2014 Conference of the Swiss Society for Financial Market Research, and the 2013 Southern Finance Association (SFA) Annual Meeting for useful comments. We thank Minjie Huang for research assistance, and Suzanna Emelio and Anthony Pawlicki for editorial assistance. We are especially grateful to S.P. Kothari (the editor) and to Eric So (the referee) for their comments, insights and guidance. Any errors of analysis and interpretation are ours.

Email addresses: akbas@ku.edu (Ferhat Akbas), meschke@ku. edu (Felix Meschke), jwintoki@ku.edu (M. Babajide Wintoki)
} 


\section{Introduction}

Corporate directors have access to material non-public information, which makes them a potential information source for professional traders. Directors are, of course, required to keep sensitive material private: Delaware law recognizes a director's duty of confidentiality, and corporations have comprehensive policies in place to prevent leaks. Investors, too, face regulatory scrutiny and reputational costs if they use inside information in traceable manners, and these safeguards seem to be effective in some institutional settings (Griffin, Shu, and Topaloğlu, 2012). However, sensitive information can travel through education networks from senior corporate officers to mutual fund managers and sell-side analysts (Cohen, Frazzini, and Malloy, 2008, 2010). This raises an important question: to what extent do director networks transmit information that sophisticated traders are able to exploit?

We investigate whether the breadth of directors' professional connections systematically affects the likelihood of information leakage to sophisticated traders. Well connected directors interact with scores of people, and unguarded conversations can easily reveal sensitive facts. In addition, Larcker, So, and Wang (2013) show that firms benefit from more connected boards because board connections are a conduit of information exchange. Yet an important competitive advantage of connected directors stems from their ability to provide insights that would otherwise be inaccessible to less connected colleagues. Fulfilling this role might require some deliberate sharing of sensitive material. Sophisticated traders, who gather, analyze and interpret data from multiple sources, have a comparative advantage when piecing together information about firms with highly connected directors. We therefore study possible information transmission from corporate directors to sophisticated traders by examining the relation between board connectedness and the informativeness of trades made by short sellers, option traders, and institutional investors.

Our results indicate that these investor groups are indeed more informed when trading stocks of companies with more connected boards. We measure informed trading as the monthly level of short interest, the ratio of monthly option volume to stock volume, and weekly order imbalances 
of institutional traders. From BoardEx, we obtain the number of first-degree connections for each director, which includes links through educational institutions attended, current and previous employers, military service and civic institutions. To ensure that our measure of board connectedness is not driven by factors that have been documented to affect the firm's information environment, we first aggregate the connections of all board members and then orthogonalize them with respect to firm size, board size, firm age, the number of analysts and institutional ownership. We examine portfolios sorted by board connectedness and each of the three measures of informed trading and find that the annualized return difference between the highest and lowest quintile of informed trading in highly connected boards is significantly more pronounced compared to the same return difference in firms with less connected boards. The economic magnitude ranges from $4 \%$ for option volume and $5.4 \%$ for short interest, to $7.2 \%$ for institutional order imbalance.

Next, we examine whether the trades of sophisticated investors predict changes in firm fundamentals. Our results indicate that a higher fraction of negative earnings news is embedded in prices of highly connected firms ahead of the announcement, and that sophisticated traders better anticipate earnings surprises in firms with highly connected boards. Indeed, their trades predict firm-specific news content more broadly, as our analysis of Thompson Reuters' public news data shows. Changes in board connectedness are also positively associated with changes in measures of adverse selection costs, such as the probability of informed trading (PIN), bid-ask spreads and the price impact measure of Amihud (2002). In a series of robustness checks we establish that neither family ownership, corporate governance quality, nor asset tangibility, drive our findings.

Our study contributes to several strands of the literature. First, we add novel insights to recent studies examining the role of director networks in financial markets. Among directors these networks contribute to higher firm performance (Larcker et al., 2013), the dissemination of CEO compensation practices (Wong, Gygax, and Wang, 2015), stock option backdating (Bizjak, Lemmon, and Whitby, 2009), and earnings management (Chiu, Teoh, and Tian, 2012). Board members and their social networks influence which companies become targets in change-of-control transac- 
tions (Stuart and Yim, 2010). Directors of Finnish firms earn sizable abnormal returns by trading stocks where they have information advantages through their board connections (Berkman, Koch, and Westerholm, 2014). We build on these insights by documenting that board connections in general affect the external corporate information environment, increase the potential for informed trading, and facilitate the dissemination of information into stock prices. While prior research suggests that analysts, media outlets and managers have incentives to convey positive news (McNichols and O'Brien, 1997; Kothari, Shu, and Wysocki, 2009), we show that negative news, in particular, flows through director networks.

Second, we contribute to research into the information sources of sophisticated traders. Short sellers predict the outcome of earnings surprises (Christophe, Ferri, and Angel, 2004), detect financial misconduct (Karpoff and Lou, 2010), and uncover hidden bad news in high levels of accruals (Hirshleifer, Teoh, and Yu, 2011). Short sellers excel in processing publicly available news (Engelberg, Reed, and Ringgenberg, 2012) and receive tips ahead of analyst downgrades (Christophe, Ferri, and Hsieh, 2010). Option trades (Pan and Poteshman, 2006; Johnson and So, 2012) and institutional trades (Griffin, Harris, and Topaloğlu, 2003; Campbell, Ramadorai, and Schwartz, 2009; Puckett and Yan, 2011) also predict future stock prices. Our findings suggest that more connected directors contribute, directly or inadvertently, to the information set of short sellers, option traders, and institutional investors. More generally, we advance an emergent literature that examines how a firm's organizational structure affects its information environment. Anderson, Reeb, and Zhao (2012) report that family ownership increases informed trading. We complement their findings by directly linking the governance structure of the firm to sophisticated trading in the firm's stock.

\section{Identification strategy and hypotheses development}

How does material non-public information flow from corporate insiders to sophisticated investors? What organizational characteristics restrain or exacerbate the magnitude of information transmission? How does this affect trading and security prices? These questions, while essential 
to understand, are difficult to answer. Insiders can be found on every level of the corporate hierarchy, the sophistication of traders is not readily apparent, both groups have incentives to keep their conversations about privileged information secret, and traders frequently disguise trades that could trigger regulatory attention. In light of these challenges, we develop a novel identification strategy that focuses on the possible information transmission between two important groups of people: we investigate whether patterns in trading behavior and securities prices suggest that privileged information flows from corporate directors to sophisticated traders.

By focusing on the board of directors, we study a group of clearly identifiable corporate insiders with privileged information about their firms. Unfettered access to material, non-public information is necessary to monitor and advise management, the social networks of directors are observable, and recent studies suggest that these networks are important conduits of information exchange. We argue that sophisticated traders can obtain privileged information from directors and trade profitably on that information before it becomes available to the broader market. If information is channeled towards sophisticated traders, their profitability will be high. In contrast, if connected directors disseminate sensitive information broadly, prices will quickly incorporate it, leaving smaller profit opportunities for sophisticated traders. As possible transmission channels we consider inadvertent information leakage, deliberate sharing of sensitive information, and 'mosaic' information gathering. We discuss each channel in turn.

The risk of inadvertent information leakage increases with the size of the network of people who are privy to material non-public information. ${ }^{1}$ Steele (1989) formalizes this idea, and models the likelihood of disclosing a secret as proportional to the square of the number of people who know the secret. More connections increase the difficulty of guarding against the unintended disclosure of private information. We therefore expect that inadvertent information leakage will be more pronounced for companies with more connected boards.

\footnotetext{
${ }^{1}$ Frederick C. Klein. "Merger Leaks Abound Causing Many Stocks to Rise Before the Fact." Wall Street Journal 192 (12 July 1978), cited in Keown and Pinkerton (1981).
} 
Directors also face incentives to share sensitive information deliberately. After all, an important competitive advantage of broadly connected directors stems from their ability to obtain and share insights that would otherwise be inaccessible to less connected colleagues. Molm (2003) suggests that reciprocal information sharing increases the status and influence of an individual within a network. Fisman, Fisman, Galef, Khurana, and Wang (2012) remark that "board membership more broadly creates a context for a kind of reciprocal attraction and friendship among a fraternity of individuals." While SEC enforcement actions allege that directors have deliberately provided information to traders, ${ }^{2}$ our study does not assess the legality of directors' actions. Reciprocal sharing of sensitive material by connected directors does not necessarily harm shareholders; the benefits of connectedness may outweigh the costs. Incentives related to reciprocal sharing simply suggest that highly connected directors are more likely to divulge some sensitive information.

More connected directors may increase the amount of publicly available information in ways that favor 'mosaic' information gathering by sophisticated investors. Jarrell (2011) argues: “Securities analysts and investment managers legally gather, analyze and interpret large quantities of information from multiple sources. From this information, investment recommendations and decisions are routinely made. Not until the 'bits and pieces' of stray information are compiled together into a 'complete picture of the company' does it sometimes reveal material, non-public information. It is my understanding that under the 'mosaic theory,' analysts and investment managers are free to act on this compilation of information without risking liability under the insider trading laws." 3 Due to their extensive networks, more connected directors provide better access to these 'bits and pieces': they are members of clubs, societies, and other firms, they are often

\footnotetext{
${ }^{2}$ For example, on October 26, 2011, the SEC charged former McKinsey global head Rajat Gupta with illegally tipping Raj Rajaratnam while serving on the boards of Goldman Sachs and Procter \& Gamble, see www.sec.gov/news/press/2011/2011-223.htm. On September 20, 2012, the SEC charged a former member of the board of directors at a North Carolina-based insurance company with illegally tipping inside information about an impending merger, see www.sec.gov/news/press/2012/2012-193.htm.

${ }^{3}$ See SEC v. Galleon Mgmt., LP, et al., Civil Action No. 09-CV-8811 (S.D.N.Y) (JSR), Expert Report of Gregg A. Jarrell (April 29, 2011, page 16).
} 
invited to give speeches, and frequently interpret publicly available information about their firm. While most investors lack the resources to piece together this kind of public information, sophisticated traders physically track directors, ${ }^{4}$ comb through public records of their large consumer and asset purchases and attend their invited speaking events. Some directors are even spied on. ${ }^{5}$ The more connected the members of corporate boards are, the greater the amount of difficult-to-process information that sophisticated trades might be able to access.

While inadvertent information leakage, deliberate tipping, and 'mosaic' information gathering are three possible channels of information transmission, it is not clear that companies with more connected directors are indeed associated with more informed trading: Federal regulations prohibit selective disclosure, Delaware law recognizes the duty of confidentiality as part of a director's duty of loyalty, and corporate lawyers have developed comprehensive confidentiality policies to prevent leaks. In addition, Griffin et al. (2012) argue that institutional investors are reluctant to use inside information in traceable manners. Our null hypothesis is that there is no systematic link between board connectedness and informed trading.

Banerjee and Eckard (2001), however, doubt that insider trading regulations effectively limit informed trading. Many studies document informed trading among short sellers, option traders and institutional investors, and more connected boards might increase the information flow to these sophisticated traders. The information channels that we identify are not the only possible ones, they are not necessarily illegal or mutually exclusive, and we are not assessing their relative importance. Our alternative hypothesis simply states that sophisticated investors' trades are more informed when they trade shares in firms with more connected boards.

\footnotetext{
${ }^{4}$ On December 3, 2012, CNBC's John Carney reported on "a fund manager who was allegedly paying off people to discover who was coming in and out of Teterboro Airport, the small New Jersey airport catering to many New York area private corporate jets," see www.cnbc.com/id/100272132 (accessed 3/4/2016).

${ }^{5}$ On October 20, 2011, Jim Finkle of Reuters reported that hackers installed malicious software on the Nasdaq's computer system to spy on directors of publicly traded companies, see www.reuters.com/article/2011/10/20/us-nasdaqhacking-idUSTRE79J84T20111020 (accessed 3/4/2016).
} 


\section{Sample selection, variables and descriptive statistics}

\subsection{Sample selection}

The BoardEx database tracks connections of corporate directors and executives from 2002 onward. Since we rely on BoardEx to quantify board connections, our sample period begins in January 2002 and ends in December 2011. Stock prices, trading volume and shares outstanding are from CRSP, book-to-market ratios, leverage, ROA, R\&D, industry segments, and other accounting variables are from COMPUSTAT, options data come from Ivy OptionMetrics, institutional ownership and insider trading data are provided by Thomson Financial, and analysts' forecasts by $\mathrm{I} / \mathrm{B} / \mathrm{E} / \mathrm{S}$. We limit our analysis to common stocks (share code 10 or 11) of non-financial firms traded on AMEX, NYSE, or NASDAQ and require stocks to have at least twelve months of past return data, at least ten days per month with available trades and return data, a month-end stock price above one dollar, and sufficient data from COMPUSTAT to compute accounting ratios as of December of the previous year.

\subsection{Measures of informed trading}

In our analysis we use three measures of informed trading. Our first measure is the monthly level of Short Interest, defined as current shares sold short divided by total shares outstanding. Monthly short interest data are available for the entire sample period for which we have board characteristics and options data. Several studies, including Asquith, Pathak, and Ritter (2005), Desai, Krishnamurthy, and Venkataraman (2006) and Karpoff and Lou (2010) use monthly short interest as a measure of short selling activity, and document that short interest contains negative information about stock prices and future firm fundamentals. Boehmer, Huszar, and Jordan (2010) argue that absence of short interest can be viewed as a signal of good news. Thus, short interest can signal bad news by its presence, or good news by its absence.

Our second measure of informed trading is the ratio of total monthly put and call trading volume to stock trading volume, or Option/Stock volume. Pan and Poteshman (2006) provide evidence 
of informed trading by using proprietary Chicago Board Options Exchange (CBOE) option market data. More recently, Johnson and So (2012) report that Option/Stock volume contains negative information about future stock prices.

Our third measure of informed trading is institutional trading order imbalances. Griffin et al. (2003), Campbell et al. (2009), and Puckett and Yan (2011) document that institutions are informed traders whose trades predict stock returns. To measure institutional trading, we use the weekly trading order imbalance of institutional traders in each stock. The trading order imbalance, Institutional $O I B$, measures whether the observed weekly trading volume is dominated by institutional buying or selling. We obtain transaction level data on institutional trading from Ancerno Ltd. for the period from 2002 to 2011. For each stock, we calculate order imbalance as buyer minus seller initiated institutional trading over a week, normalized by total institutional trading activity measured as the total number of shares traded. A positive institutional trading order imbalance indicates that institutions are net buyers, and a positive relation between weekly order imbalance and future returns suggests that institutions are informed traders. We expect this relation between Institutional $O I B$ and subsequent returns to be more pronounced for firms with more connected boards. Following Johnson and So (2012), we transform all informed trading measures into decile ranks and use the decile ranks of these variables in multivariate regressions that feature the particular informed trading measure.

\subsection{Measuring board connectedness}

We obtain connections for each director from the BoardEx database and aggregate them at the board level. This straightforward measure of board connections merely enumerates the number of first-degree links for all directors on the board. This includes connections through educational institutions attended, current and previous employers, military service as well as civic institutions like non-profit boards. ${ }^{6}$ Yet this simple aggregation suffers from two obvious drawbacks. First,

\footnotetext{
${ }^{6}$ The same degree measure is used by Larcker et al. (2013). They also construct three additional measures of board centrality and show in their Table 3 that this degree measure is highly correlated with all of them: The Spearman
} 
by construction, this aggregation increases mechanically with the number of directors, leading to a Spearman rank correlation of more than 0.6 between board size and aggregate connections.

Second, several factors have been identified in the literature to affect the firm's information environment and the potential returns from informed trading, which are also correlated with aggregate director connections. For example, firm size affects the quality and quantity of information that can be exploited by informed traders (Hong, Lim, and Stein, 2000), but directors of larger firms tend to be more connected within the BoardEx universe. Similarly, Zhang (2006) argues that firm age captures differences of opinion related to future events, but directors of older firms have more aggregate connections. Firms with more analyst following are also likely to have more connected directors, but the amount of analyst coverage directly affects the information available about the firm (Hong et al., 2000). Finally, D'Avolio (2002) provides evidence that institutional ownership measures shorting costs because it affects the supply of lendable shares, and Cohen, Diether, and Malloy (2007) document that the ability to exploit information depends on the ability to access loaned shares. At the same time, directors of firms with more institutional investors also tend to have more connections.

To ensure that our measure of board connectedness is not driven by any of these factors, we regress the natural logarithm of aggregate board connections on the natural logarithms of firm size, board size, firm age, number of analysts, and on institutional ownership, and use the residual values from these year-end cross-sectional regressions, which we term Connectedness, to categorize firms in our sample.

\subsection{Additional control variables}

Beyond orthogonalizing our Connectedness measure with respect to factors that have been shown to jointly affect opportunities for informed traders and aggregate director connections, we account in our multivariate regressions for characteristics of the firm's information and contract-

correlation is 0.94 for their closeness, 0.92 for their betweenness, and 0.91 for their eigenvector measure. 
ing environment that might affect board characteristics or the measures of informed trading. For example, growth opportunities (book-to-market) are an important proxy of the corporate information environment that has been shown to affect a firm's governance choices. However, firms that are growing more slowly are less opaque, have less information uncertainty, and hence, lower opportunities for informed trading (Hong et al., 2000; Zhang, 2006). In contrast, higher research and development (R\&D) expenses lead to greater information asymmetry (Aboody and Lev, 2000, among others), and complex firms, which operate in different industries or distinct business segments, have slower information diffusion (Cohen and Lou, 2012). Because these attributes could attract informed traders and also affect board characteristics, we include in our analysis $R \mathcal{E} D$ expenditure and the number of business segments in which the firm operates. We also control for return on assets (ROA) since it attracts informed traders' attention. We include liquidity, turnover and return volatility (IVOL) in our analysis to ensure that our results are not driven by differences in the cost of exploiting information (Pontiff, 2006) and include past return to control for shortterm reversal or medium-horizon stock price continuation (Jegadeesh and Titman, 1993). Table 1 provides definitions for all control variables.

\subsection{Descriptive statistics}

Table 2 presents time-series averages of cross-sectional statistics for all companies in our sample. Since the number of available observations differs for our three measures of informed trading, we report monthly statistics for the Short Interest sample in Panel A, for the Option/Stock volume ratio sample in Panel B, and weekly statistics for the Institutional OIB sample in Panel C. The average board in our BoardEx sample has around 4,000 aggregate connections. The distribution of aggregate connections is skewed, with a median and standard deviation of around 3,000, and a range from 225 to over 24,000 connections. After orthogonalization, which we describe in section 3.4, Connectedness (which is in natural logs) ranges from -1.7348 to 1.0987 in the Short Interest sample, from -1.5636 to 1.0158 in the Option/Stock volume sample, and from -1.7468 to 1.0900 in the Institutional OIB sample. For the Short Interest and Institutional OIB samples, the average 
firm is around 25 years old and has a market capitalization that exceeds one billion dollars. The Option/Stock volume sample requires companies with traded options, which limits us to companies that are slightly older and larger: the average firm is around 26 years old with a market capitalization that exceeds seven billion dollars. Other firm characteristics do not notably differ across the three samples. Average Short Interest is $4.9 \%$, average Option/Stock volume is $3.8 \%$, and the average Institutional OIB is $5.0 \%$.

Table 3 presents times series averages of cross-sectional Spearman rank correlations. Here again, we report statistics for the Short Interest sample in Panel A, the Option/Stock volume sample in Panel B, and the Institutional OIB sample in Panel C. The correlations illustrate why we orthogonalize aggregate connections to create the Connectedness measure. Aggregate connections is highly correlated with several firm characteristics. Panel A reveals that the correlation coefficient is 0.61 for firm size, 0.62 for board size, 0.20 for firm age, 0.14 for the number of analysts, and 0.46 for institutional ownership. By orthogonalizing we create a Connectedness measure that is highly correlated with aggregate connections, yet largely uncorrelated with firm characteristics that have been documented to affect the prevalence of informed trading. While the correlation coefficient between Connectedness and aggregate connection is 0.7 , the correlations with firm size, board size, firm age, number of analysts, and institutional ownership do not exceed 0.03. Connectedness effectively measures the cross-sectional variation in board connections, yet is far less likely to reflect differences in the firm's information environment.

\section{Connectedness, informed trading, and stock returns}

In this section we investigate the link between stock returns and informed trading across firms with different Connectedness. We expect a stronger relation between our measures of informed trading and future returns for companies with more connected boards. 


\subsection{Portfolio analysis}

We begin our analysis by sorting stocks into equal groups of low, medium, and high board Connectedness, and then into quintiles based on the level of informed trading. In the Short Interest and Option/Stock volume samples, portfolios are formed at the beginning of every month, held for a month after portfolio formation, and portfolio returns are calculated as equally-weighted averages of monthly stock returns. In the Institutional OIB sample, portfolios are formed every week, held for a week after portfolio formation, and portfolio returns are calculated as equallyweighted averages of weekly stock returns. We report time series averages alphas ( $\alpha \mathrm{s})$ from the Fama-French three factor model (Fama and French, 1993), augmented with a momentum factor (Carhart, 1997). All tests of statistical significance are based on Newey-West standard errors.

Panel A of Table 4 displays portfolio results for the Short Interest sample. The first column, labeled $A l l$, aggregates the Connectedness groups and confirms that, consistent with previous studies, Short Interest is negatively associated with subsequent stock returns. For the three lowest short selling quintiles we find that subsequent returns are higher for more connected boards, which is consistent with Larcker et al. (2013). Whereas Larcker et al. (2013) look at average returns across connectedness portfolios, we examine informed trading within connectedness portfolios. We find that the difference in risk-adjusted returns $(\alpha \mathrm{s})$ between the highest and lowest Short Interest quintile (S5 - S1) for the high Connectedness group is $-1.161 \%$, per month. In contrast, the same difference is only $-0.681 \%$ in the medium Connectedness group and $-0.697 \%$ in the low Connectedness group.

Put differently, the novel finding of our study is that the risk-adjusted return between the high and low Short Interest groups (S5 - S1) is $0.464 \%$ per month more negative for firms with highly connected boards than for firms with less connected boards, and this difference is statistically significant at the one percent level $(t$-statistic $=-3.89)$. This means that the annualized return difference between the highest and lowest quintile of Short Interest in firms with highly connected boards is about $5.4 \%$ more negative than the same return difference for firms with less connected 
boards. High Short Interest predicts negative returns more strongly in firms with well connected directors.

Panel B reports results for the Option/Stock volume sample. Again, the column labeled All aggregates the Connectedness groups and indicates that Option/Stock volume is negatively associated with future stock returns as documented by Johnson and So (2012). Consistent with the results for Short Interest in Panel A, the difference in risk-adjusted returns between the highest and lowest Option/Stock volume quintile $(\mathrm{O} / \mathrm{S} 5-\mathrm{O} / \mathrm{S} 1)$ is $0.340 \%$ per month more negative for firms with highly connected boards than for firms with less connected boards, and this difference is again statistically significant at the one percent level $(t=-2.64)$. High Option/Stock volume also predicts negative returns more strongly in firms with well connected directors.

Panel C presents results for the Institutional OIB sample. For each stock in the Ancerno database the institutional trading imbalance (Institutional $O I B$ ) is constructed as institutional buys minus institutional sells over a week. Unlike short interest or options trading, where informed trading is associated with negative returns, higher Institutional OIB is associated with positive returns, and lower Institutional $O I B$ with negative returns. Consistent with the short interest and option trading results, the risk-adjusted return between the high and low institutional order imbalance groups (OIBS5 - OIBS1) is $0.134 \%$ per week more positive for firms with highly connected boards than for firms with less connected boards, and this difference is statistically significant at the five percent level $(t=2.14)$. This means that the annualized return difference between the highest and lowest quintile of institutional order imbalance in firms with highly connected boards is about $7.2 \%$ higher than the same return difference for firms with less connected boards.

We also examine time-varying patterns in return predictability within low and high connected boards to ensure that our results are not driven by a specific time period. For example, our findings could be affected by the passages of Regulation Fair Disclosure or the Sarbanes-Oxley Act, which restrict corporate information sharing and governance structure. Yet when we plot the annual quintile hedge return for each connectedness tercile in Figure 1, we see no clear time-series pattern. All 
three informed trading measures predict stock returns more strongly in firms with well connected directors, and these results are not driven by a particular subperiod. The results could be impacted by other stock characteristics, so we investigate that possibility next.

\subsection{Multivariate regressions}

In this section, we extend the portfolio analysis from Section 4.1 by performing cross-sectional multivariate regressions. These regressions allow us to control for various other stock characteristics that could potentially affect the relation between our informed trading measures and returns across different levels of Connectedness. In particular, we estimate Fama and MacBeth (1973) regressions of subsequent returns on the informed trading measures, Connectedness, and the interaction between the two, while controlling for several firm characteristics:

$$
\operatorname{Return}_{i, t+1}=\alpha+\beta_{1} M_{i, t}+\beta_{2} \text { Connectedness }_{i, t}+\beta_{3} M_{i, t} \times \text { Connectedness }_{i, t}+\beta_{4} \text { Controls }_{i, t}+\epsilon_{i, t},
$$

where $M_{i, t}$ is one of our three informed trading measures: Short Interest, Option/Stock volume, or Institutional OIB. The dependent variable is monthly return for the Short Interest and Option/Stock volume samples, and weekly return for the Institutional OIB sample. If sophisticated traders are more informed when trading stocks in firms with more connected boards, then we expect a negative coefficient on the interaction term $\left(\beta_{3}<0\right)$ for the Short Interest and Option/Stock volume samples, and a positive coefficient $\left(\beta_{3}>0\right)$ for the Institutional OIB sample.

The multivariate regression results in Table 5 support these predictions and corroborate the portfolio results. The estimated coefficient on the interaction between the informed trading variable, $M_{i, t}$, and Connectedness are $-0.395(t=-2.81)$ for Short Interest, $-0.513(t=-2.59)$ for Option/Stock volume, and $0.094(t=2.10)$ for Institutional OIB. The positive and statistically significant coefficient on the direct effect of Connectedness in the first two columns confirms previous results by Larcker et al. (2013). Yet even after controlling for additional stock characteristics, we find that short interest, options trading and institutional trade order imbalances contain more information about future stock returns if the firms' boards are more connected. 


\section{Board connectedness, informed traders and earnings surprises}

Our analysis so far suggests that the information content of short interest, options trading and institutional order imbalances, as inferred from return predictability, is higher among firms with more connected boards. In this section, we examine the role of firm Connectedness on the relation between informed trading prior to earnings announcements and the earnings surprise. Earnings announcements are scheduled events that often convey substantial information about firm fundamentals. If information transmission from boards provides private information about the future prospects of the company, then trades of these investors should contain information about future changes in firm fundamentals. We therefore expect a stronger relation between our informed trading measures prior to earnings announcements and subsequently announced earnings surprises for companies with more connected boards.

We estimate quarterly Fama-MacBeth (1973) regressions of earnings surprises on the informed trading measures, Connectedness, and the interaction between the two, while controlling for several firm characteristics. In other words, we run regressions of the form:

Earnings Surprise $_{i, q}=\alpha+\beta_{1} M_{i, q}+\beta_{2}$ Connectedness $_{i, q}+\beta_{3} M_{i, q} \times$ Connectedness $_{i, q}+\beta_{4} \operatorname{Controls}_{i, q}+\epsilon_{i, q}$,

$M_{i, q}$ is one of our three informed trading measures: Short Interest, Option/Stock volume, or Institutional OIB. These are measured one month prior to the month of the earnings announcement in the case of Short Interest and Option/Stock volume, or the week prior in the case of Institutional OIB.

We use three different measures of earnings surprises: Unexpected Earnings, Standardized Unexpected Earnings (SUE) and Analyst Surprise. Unexpected Earnings is calculated as (EPS $S_{i, q}-$ $\left.E P S_{i, q-4}\right) / P_{i, q-4}$, where $E P S_{i, q}$ and $E P S_{i, q-4}$ are earnings per share before extraordinary items for firm $i$ in quarters $q$ and $q-4$, respectively, and $P_{i, q-4}$ is the stock price in quarter $q-4$. Standardized Unexpected Earnings (SUE) is patterned after Bernard and Thomas $(1989,1990)$ as $\left(E P S_{i, q}-E P S_{i, q-4}-\mu_{i, q}\right) / \sigma_{i, q}$, where $\mu_{i, q}$ and $\sigma_{i, q}$ are the mean and standard deviations of earnings changes $\left(E P S_{i, q}-E P S_{i, q-4}\right)$ in the previous eight quarters. Analyst Surprise is the difference 
between actual earnings per share (EPS) reported in $\mathrm{I} / \mathrm{B} / \mathrm{E} / \mathrm{S}$ in quarter $q$, and the median of the most recent forecasts made by analysts following the firm over the 90 days prior to the earnings announcement; this difference is then scaled by $P_{i, q-4}$. We employ the same control variables as in Table 5, which are all measured one month prior to the month of the earnings announcement. As before, we expect a negative coefficient on the interaction term $\left(\beta_{3}<0\right)$ for the Short Interest and Option/Stock volume samples, and a positive coefficient $\left(\beta_{3}>0\right)$ for the Institutional OIB sample.

Columns (1) - (3) of Table 6 indicate that our measures of informed trading predict unexpected earnings more strongly in firms with more connected boards. The estimated coefficient on the interaction between the informed trading variable and Connectedness is $-0.681(t=-2.52)$ for Short Interest and $-0.439(t=-3.69)$ for Option/Stock volume. The same coefficient in the Institutional OIB sample is positive, as predicted, but falls short of being statistically significant at conventional levels $(0.259, t=1.42)$. We find similar results when we use $S U E$ as our measure of earnings surprise in columns (4) - (6). Both Short Interest and Option/Stock volume predict SUE more strongly in firms with more connected boards; the estimated coefficient on the interaction between the informed trading variable and Connectedness is $-5.640(t=-3.07)$ for Short Interest and $-4.884(t=-2.26)$ for Option/Stock volume when the dependent variable is SUE. Results are less precise when we use Analyst Surprise to measure earnings surprise in columns (7) - (9), but even here we find that both Option/Stock volume $(\beta=-0.046, t=-1.99)$ and Institutional OIB $(\beta=0.041, t=1.78)$ predict unexpected earnings more strongly in firms with more connected boards. Taken together, these results corroborate our previous findings that sophisticated traders have some information advantage when trading stocks of firms with more connected directors.

These results are consistent with our hypothesis that informed traders are capitalizing on advanced knowledge of earnings information. An alternative interpretation would suggest that highly connected directors actually guard sensitive information more effectively, that therefore their firms are more likely to be misvalued, and that sophisticated investors successfully exploit this misval- 
uation. ${ }^{7}$ This alternative explanation also predicts, for opposite reasons, more profitable informed trading in firms with more connected boards. One way of distinguishing these two alternative explanations is to examine how news gets embedded into prices ahead of important information events such as earnings announcements.

Kothari et al. (2009) show that stock prices incorporate a greater fraction of total earnings news ahead of positive earnings announcements when compared to negative earnings announcements, suggesting that managers withhold bad news relative to good news. If highly connected boards increase inadvertent or deliberate information leakage to sophisticated traders, a greater fraction of earnings news should be embedded into prices ahead of the earnings announcements in highly connected firms. In contrast, if highly connected directors better guard sensitive information than less connected directors, a greater fraction of earnings news should be embedded into prices prior to announcements in less connected firms.

To investigate this assertion we plot stock returns prior to earnings announcements for the high and low board Connectedness groups. We present scaled cumulative average abnormal returns for good news and bad news over a three-month period leading up to the earnings announcements. We classify the lowest decile of earnings surprises as bad news and the highest decile of earnings surprises as good news. Following Kothari et al. (2009) we use the total return over the window to scale returns, which provides an estimate of the fraction of total news revealed over that time period. If more news is leaked prior to earnings surprises, we expect a higher fraction of news to be revealed over time.

For the high and low board Connectedness groups, we present results for bad news in Panel A, and results for good news in Panel B of Figure 2. The graphs in Panel A show that firms with highly connected boards release about $87 \%$ of bad news ahead of earnings announcements, while firms with less connected boards release about $63 \%$ of bad news. In contrast, Panel B shows no

\footnotetext{
${ }^{7}$ We thank the editor for bringing this argument to our attention.
} 
discernible difference between the high and low board Connectedness groups. This finding indicates that a greater fraction of negative news is revealed for highly connected firms, which suggests that highly connected directors more readily facilitate the transmission of privileged information; it does not support the argument that highly connected directors are better stewards of privileged information than less connected directors.

At first glance, Figure 2 might suggest that the potential return for short sellers ahead of bad earnings news in highly connected firms is lower than the potential return in less connected firms. This would seem to contradict the central finding in our paper that short sellers who trade in stocks of firms with highly connected boards earn higher profits than those who trade in stocks of less connected firms. However, this inconsistency arises only if one assumes that, prior to earnings announcements, short sellers are equally likely to trade ahead of bad news in both highly and less connected firms. This is not the case; short sellers trade more readily in stocks of more connected firms because they are able to obtain more privileged information about them. In other words, the information flow ahead of earnings is not broadly disseminated, but is channeled towards sophisticated traders. These traders are thus more often correct when trading in stocks with highly connected boards, and, hence, earn higher profits.

\section{Board connectedness, informed traders and firm-specific news sentiment}

Sophisticated traders predict stock returns more accurately for firms with more connected boards, and some information transmission occurs, apparently, prior to quarterly earnings disclosures. In addition to corporate earnings, directors are privy to a wide variety of value-relevant information such as new product launches, acquisitions, restructurings, layoffs, accounting restatements, loss of major contracts, or departures of key executives. In this section, we investigate whether the trades of short sellers, option trader, and institutional investors more strongly predict the sentiment of firm-specific news for firms with more connected boards. For those firms we expect that higher Short Interest, higher Options/Stock volume, and lower Institutional OIB bet- 
ter predict negative corporate news, while lower Short Interest, lower Options/Stock volume, and higher Institutional OIB better predict positive corporate news.

To test this prediction, we estimate Fama-MacBeth (1973) regressions of firm-specific news Sentiment on each of the informed trading measures $\left(M_{i, t}\right)$, Connectedness, and the interaction between the two, while controlling for several other firm characteristics:

$$
\text { Sentiment }_{i, t+1}=\alpha+\beta_{1} M_{i, t}+\beta_{2} \text { Connectedness }_{i, t}+\beta_{3} M_{i, t} \times \text { Connectedness }_{i, t}+\beta_{4} \text { Controls }_{i, t}+\epsilon_{i, t} \text { (3) }
$$

As before, $M_{i, t}$ denotes Short Interest, Option/Stock volume, or Institutional OIB.

The dependent variable, Sentiment, is a text-based sentiment measure of firm-specific news in the media, aggregated over a month or a week. The data come from Thomson Reuters News Analytics and are available from 2003. Thomson collects corporate news items from public sources, uses computational linguistics to classify each item according to its relevance, sentiment, novelty, and topic, and provides three sentiment scores for each item: negative, neutral and positive. Each score takes a value from 0 to 100 , but the scores in the three categories always sum to 100 . Higher scores in a specific sentiment category indicate that the news is more likely to belong to that category. For each news item, we calculate the difference between positive and negative sentiment scores, so that a higher difference reflects a more positive news content. For each firm, we average across these differences to obtain our measure of monthly or weekly firm-specific news Sentiment. To ensure that our firm-specific sentiment measure is based on novel fundamental news about individual companies, we exclude news items categorized as 'order imbalances' or 'stock prices' to eliminate news stories that simply mention stock price movements. We also exclude news with a 'relevance score' below 50 to capture only firm-specific news, and we eliminate repeated news. ${ }^{8}$

The results of our news sentiment analysis are presented in Table 7. Our measures of informed trading predict not only earnings surprises more strongly in firms with more connected boards,

\footnotetext{
${ }^{8}$ Thomson's 'relevance score' takes a value from 0 to 100 , where a higher value indicates that the firm is a more important subject of the news story. Thomson's 'novelty' variable provides the number of related news items over the previous 24 hours; we exclude news items with novelty scores greater than one.
} 
but also firm-specific news sentiment: The estimated coefficient on the interaction between the informed trading variable and Connectedness is $-1.4454(t=-2.32)$ for Short Interest, -1.639 $(t=-3.07)$ for Option/Stock volume, and $1.242(t=2.26)$ for Institutional OIB. Taken together, the results in Tables 6 and 7 suggest that sophisticated traders have greater insights about upcoming earnings and firm-specific news when trading stocks in firms with more connected boards.

\section{Alternative explanations, robustness tests, and corroborating evidence}

Short sellers, option traders, and institutional investors seem to be more informed about upcoming earnings and news of firms with highly connected boards, and their trades predict stock returns better as Connectedness increases. In this section, we focus on three alternative explanations for our findings by examining the role of family ownership, corporate governance and asset tangibility. These factors could influence the firm's information environment and strengthen the relation between informed trading and subsequent stock returns, while also being related to the Connectedness of the firm. We also perform a battery of other robustness tests.

\subsection{Family ownership}

In a recent study, Anderson et al. (2012) find more informed short sales in family-controlled firms than in firms with diffuse ownership. If family-owned firms also happen to have more connected boards, our results might be due to ownership characteristics. To explore this possibility, we create a family firm indicator variable using the definition of family firm and data from Anderson et al. (2012). We then replicate the multivariate regressions tests from Table 5 and include the family firm indicator by itself, as well as an interaction of the family firm indicator and our measures of informed trading, as additional control variables. The findings are reported in Panel A of Table 8. In our analysis, for each measure of informed trading, we report results with and without Connectedness.

Consistent with Anderson et al. (2012), short sellers appear to be more informed when trading the shares of family firms, yet accounting for family firm status does not change our inference: 
measures of directional trading by sophisticated investors are stronger predictors of future returns among firms with more connected boards. These findings might not be surprising; Anderson and Reeb (2004, p. 221, Table1) document that family firms do not differ from other firms with respect to board size, and board size and board Connectedness are highly correlated. Anderson et al. (2012) link trading by sophisticated investors to ownership structure while our study links it to an aspect of board structure. The two phenomena appear to be distinct.

\subsection{Corporate governance}

Effective governance can enhance financial transparency by mitigating executives' incentives to distort information disclosures (Leuz, Nanda, and Wysocki, 2003) and may increase operational transparency by limiting executives' ability to expropriate firm value through shirking, empire building, or perquisite consumption (Bebchuk, Cohen, and Ferrell, 2009). Chung, Elder, and Kim (2010) report that firms with better corporate governance are associated with higher liquidity and lower probability of information-based trading. This suggests that, on the one hand, governance quality affects the firms' information environment. On the other hand, several studies link governance quality to board connections. Guedj and Barnea (2009) find weaker monitoring among more connected directors, and several studies document that value-decreasing practices like option backdating can spread through board networks (Bizjak et al., 2009). Together, these studies raise the concern that our results are not indicative of information transmission through director networks to sophisticated traders; instead, weak corporate governance might be associated with higher board connections and also create an information environment more conducive to informed trading. We investigate this possibility.

To proxy for the quality of monitoring, we create the variable Outsider, which is the fraction of independent directors on the board. We replicate the multivariate regression tests from Table 5 and include Outsider by itself, an interaction term of Outsider with each measure of informed trading, as well as additional control variables. In Panel B of Table 8 we report the results first without, and then with interacted Connectedness. While the informativeness of Short Interest and Institutional 
$O I B$ seem unaffected by board independence, the positive and statistically significant coefficient for Option/Stock volume $\times$ Outsider suggests that option traders are less informed when trading stocks in firms with a greater fraction of outside directors. This finding can be interpreted as supporting the notion that stronger governance is associated with a lower probability of information-based trading (Chung et al., 2010). Even so, accounting for the fraction of outside directors does not change our inference: measures of informed trading predict returns more strongly in firms with more connected boards. In untabulated tests, we replace the fraction of outside directors with the entrenchment index (E-index) of Bebchuk et al. (2009) as an alternative measure of governance quality and confirm that our inference remains unchanged.

\subsection{Asset tangibility}

Sophisticated investors may have a distinct advantage when trading the shares of firms with high levels of intangible assets. Such firms might offer greater opportunities to exploit private information or to profit from sophisticated processing of public information. Faleye, Kovacs, and Venkateswaran (2014) argue that firms with better connected executives exploit intangible assets more efficiently because connections help CEOs identify, evaluate, and exploit innovative ideas. This raises the concern that the level of asset intangibility is correlated with Connectedness, which may, in fact, explain our results. To explore this possibility, we create an asset tangibility variable, defined as the ratio of Property, Plants, and Equipment (PPE) to total assets. We replicate the multivariate regression tests from Table 5 and include asset tangibility by itself, an interaction term of asset tangibility with each measure of informed trading, as well as additional control variables.

In Panel $\mathrm{C}$ of Table 8 we report our findings first without, and then with interacted Connectedness. The statistically significant coefficients do indeed suggest that measures of directional trade are stronger predictors of future returns among firms with more intangible assets; the estimated coefficients on the interaction between the informed trading variable and asset tangibility are $1.289(t=3.31)$ for Short Interest and $-0.189(t=-1.91)$ for Institutional OIB. However, the return predictability of trading activity by sophisticated investors remains higher among firms with 
more connected boards even after accounting for the role of asset tangibility: the estimated coefficients on the interaction between the informed trading variable and Connectedness are -0.386 $(t=-2.92)$ for Short Interest, $-0.468(t=-2.74)$ for Option/Stock volume, and $0.093(t=1.96)$ for Institutional OIB. In an additional untabulated analysis, we replace asset tangibility with the book-to-market ratio and verify that our inference remains unchanged.

\subsection{Insider trading}

Insider trading predicts future firm performance (see Cohen, Malloy, and Pomorski, 2012, for a recent review) and sophisticated traders use information contained in insider trades (Engelberg et al., 2012). If board Connectedness simply proxies for the level of insider trading, our results could be due to traders' superior ability to gather information contained in insider trading activity. To investigate this possibility we obtain insider trading data from Thomson Financial. In untabulated analysis, we repeat the multivariate analysis reported in Table 5 while controlling for both contemporaneous and lagged measures of insider trading since sophisticated traders might consider information contained in past insider trades. Even after we account for insider trading, measures of informed trading continue to predict future stock returns more strongly among stocks with more connected boards.

\subsection{Corporate employees}

It is conceivable that the degree of corporate information leakage is affected by the size of the firm's workforce. The number of people employed by the firm may be correlated with board Connectedness even after accounting for firm size, board size and other firm characteristics, and this may explain our results. To address this possibility, we include the number of employees as an additional control variable when orthogonalizing aggregate connections, thereby creating a modified Connectedness measure that explicitly accounts for the number of employees. We then replicate the multivariate regressions tests from Table 5 and include the number of employees as an additional control variable. In untabulated tests, we confirm that the number of employees does not 
explain the relation between measures of informed trading and subsequent stock returns in firms with more connected boards.

\subsection{Short flow as a measure of short selling}

So far we have used monthly Short Interest to measure short selling, which is available for the entire sample period. However, monthly Short Interest is a snapshot of the short positions at the midst of the month and may not capture the entire information flow from short sellers. While our inferences drawn from monthly Short Interest are consistent with those based on Option/Stock volume and Institutional OIB, we nevertheless investigate whether using short flow data changes our findings. To this end, we obtain transaction-level data from a pilot program under the Securities and Exchange Commission's Regulation SHO (Reg SHO). The SEC mandated Reg SHO data collection in 2005 and we collect the data through 2010. Because Reg SHO data are available for only half of our sample period, and because board Connectedness changes slowly over time, using these data limits the inferences we can draw from tests that rely on within-firm variation.

For each stock, we aggregate Reg SHO short sale trades over a week and scale it by the total number of shares traded over the same week to create a short flow variable. Analogous to our tests in Table 5 we regress returns for the subsequent week on short flow, Connectedness, and the intersection between the two. In untabulated tests, we observe that the estimated coefficient on the interaction between short flow and Connectedness is significantly negative $(-0.137, t=-1.97)$. Even when short selling is measured with short flow data, short selling predicts subsequent returns more strongly for firms with more connected boards.

\subsection{Within-firm variation in board connectedness}

Throughout this paper, our inferences have been drawn from cross-sectional differences across

firms. We predict, and show, that at any point in time, sophisticated traders are better able to predict returns, earnings, and news sentiment for firms with more connected boards than for firms with less connected boards. In this section, we investigate the effect of within-firm variation in 
board connectedness on the predictiveness of sophisticated trades. As a corporate board becomes more connected, we expect the trades of short sellers, option traders, and institutional investors to become more predictive about future returns. Since board structure is relatively persistent over our sample period, we expect that the economic magnitude of within-firm variation in Connectedness is less than the magnitude of cross-sectional firm variation. To investigate this, we carry out fixed effects regression of returns on the informed trading measures, Connectedness, and the interaction between the two, while controlling for various firm characteristics. This specification is the same as Equation (1) augmented with firm-fixed effects.

Table 9 displays firm-fixed effects regressions for our three measures of informed trading. The within-firm results are consistent with our previous findings as the estimated coefficient on the interaction between the informed trading variable and Connectedness is $-0.804(t=-2.05)$ for Short Interest, $-0.988(t=-2.09)$ for Option/Stock volume, and $0.097(t=1.79)$ for Institutional OIB. As board Connectedness increases within a particular firm, measures of informed trading predict subsequent returns to a greater extent. Similarly, as Connectedness decreases within a firm, measures of informed trading predict subsequent returns to a lesser extent. These results support our inference from other cross-sectional tests: sophisticated traders seem better informed about upcoming earnings and firm-specific news for firms with highly connected boards, and their trades predict stock returns more strongly in these firms.

\section{Board connectedness and adverse selection}

So far our findings suggest that sophisticated traders are more informed when trading stocks in firms with more connected boards. If greater Connectedness expands the private information available to investors, adverse selection should increase as well. We test this argument by examining the relation between changes in Connectedness and three measures of adverse selection: the probability of informed trading (PIN), the bid-ask spread (Spread) and Illiquidity. Our PIN measure comes from Brown and Hillegeist (2007), who extend the measure developed by Easley, Kiefer, 
and O'Hara (1997). Spread is the difference between ask and bid price divided by the mid point of the bid and ask spread, averaged over a year to obtain the average annual bid ask spread. Illiquidity is constructed as in Amihud (2002, p. 34) and measures price impact. ${ }^{9}$ The results are presented in Table 10.

In Panel A, firms are sorted into quintiles based on average annual changes in Connectedness. We report the mean change in Connectedness and the mean change in each of our three measures of adverse selection for each of the quintiles. As we move from the quintile with the largest decrease in Connectedness $(\mathrm{C} 1)$ to the quintile with the largest increase (C5), we see a corresponding change in the PIN measure. In the quintile with the largest decrease in Connectedness, PIN decreases, on average, by $0.611 \%$; in the quintile with the largest increase in Connectedness, PIN increases, on average, by $0.641 \%$. Thus, firms that have the largest annual increase in Connectedness experience an annual increase in the probability of informed trading that is $1.252 \%(t=5.49)$ greater than that experienced by firms with the largest decrease in Connectedness. This difference is economically significant given that the average PIN value in our sample is $10.63 \%$. We find similar results with respect to our two other measures of adverse selection. As we move from the quintile with the largest decrease in Connectedness $(\mathrm{C} 1)$ to the quintile with the largest increase (C5), the change in Spread and Illiquidity increase by $0.098(t=2.08)$ and $0.051(t=2.70)$ respectively. In Panel B, we carry out regressions of changes in the adverse selection measures on changes in Connectedness, while controlling for several firm characteristics. The results are in line with those from the portfolio analysis in Panel A: There is a strong positive association between changes in Connectedness and changes in all three adverse selection measures.

Taken together, the findings in Table 10 indicate that changes in Connectedness of a firm are positively associated with changes in measures of adverse selection. In a frictionless market, sophisticated traders signal through their trading the private information they have received. As soon

\footnotetext{
${ }^{9} \mathrm{We}$ are grateful to the referee for proposing this test and to Stephen Brown for generously sharing his data with us, which are based on Easley et al. (1997).
} 
as their trading activity becomes public knowledge, the remaining investors trade in the direction of the sophisticated traders until stock prices reflect the signaled information. Absent frictions, we do not expect to observe return predictability for stocks of firms with more connected boards once measures of informed trading are publicly observable. The evidence presented in this section, however, suggests that board Connectedness is associated with greater adverse selection risk. This risk might make it too costly for uninformed investors to free ride on measures of informed directional trade. It is therefore possible that we observe return predictability among firms with more connected boards because adverse selection risk prevents investors from trading on publicly available information embedded in the trades of sophisticated traders.

\section{Conclusion}

We examine information transmission between corporate insiders and sophisticated traders by studying whether board Connectedness predicts the extent to which short sellers, option traders, and institutional investors are informed. Having more connected directors on the board can increase the possibility of inadvertent information leakage. It also increases the amount of difficultto-process information, which tends to favor sophisticated investors. Some directors might even tip off traders deliberately. Consistent with our hypothesis we find that measures of sophisticated trading activity predict subsequent equity returns among firms with more connected boards. When we compare the difference in risk-adjusted returns between stocks traded the most and stocks traded the least by sophisticated investors across firms with highly connected boards and firms with low board connections, we find return differences ranging from $4 \%$ to $7.2 \%$ per year, depending on the measure employed. Sophisticated traders are better informed about upcoming earnings and firmspecific news for firms with highly connected boards. In addition, changes in board Connectedness are positively associated with changes in measures of adverse selection in trading.

In a series of robustness checks we examine alternate econometric specifications and establish that our findings are not driven by family ownership, corporate governance, asset tangibility, insider 
trading, or the number of employees. Our results are striking because federal regulations prohibit selective disclosure, Delaware law recognizes the duty of confidentiality, and corporate lawyers have developed comprehensive confidentiality policies to prevent leaks. Furthermore, most observable firm characteristics that are positively correlated with board Connectedness are negatively correlated with informed trading. While we discuss three channels through which information can flow from directors to sophisticated traders, we do not claim that these are the only transmission mechanisms and we are not assessing the relative importance of these information channels. Doing so would require more granular data than available to us, so we have to leave investigations of channel-specific information flow for future research projects. Since we cannot reliably access whether the information flow from directors to traders violates existing securities law, we caution against drawing cursory regulatory implications from our findings.

We are first in showing that the Connectedness of corporate boards, directly or inadvertently, affects the information set of short sellers, option traders, and institutional investors. These sophisticated investors exploit trading opportunities that more connected boards create and are particularly well informed about upcoming earnings and firm-specific news in firms with high board Connectedness. By directly linking corporate governance structure to the information environment in which these investors operate, we contribute to the emerging literature on director networks, and to research into the sources of traders' information. 


\section{References}

Aboody, D., Lev, B., 2000. Information asymmetry, R\&D, and insider gains. Journal of Finance $55,2747-2766$.

Amihud, Y., 2002. Illiquidity and stock returns: Cross-section and time series effects. Journal of Financial Markets 5, 31-56.

Anderson, R., Reeb, D., Zhao, W., 2012. Family controlled firms and informed trading: Evidence from short sales. Journal of Finance 67, 351-385.

Anderson, R. C., Reeb, D. M., 2004. Board composition: Balancing family influence in S\&P 500 firms. Administrative Science Quarterly 49, 209-237.

Asquith, P., Pathak, P., Ritter, J., 2005. Short interest, institutional ownership, and stock returns. Journal of Financial Economics 78, 243-276.

Banerjee, A., Eckard, E. W., 2001. Why regulate insider trading? Evidence from the first great merger wave (1897-1903). American Economic Review 91, 1329-1349.

Bebchuk, L., Cohen, A., Ferrell, A., 2009. What matters in corporate governance? Review of Financial Studies 22, 783-827.

Berkman, H., Koch, P., Westerholm, P. J., 2014. Inside the director network: When insiders trade outside stock, SSRN Working Paper, http://ssrn.com/abstract=2424527.

Bernard, V. L., Thomas, J. K., 1989. Post-earnings-announcement drift: Delayed price response or risk premium Supplement, 1-36.

Bernard, V. L., Thomas, J. K., 1990. Evidence that stock prices do not fully reflect the implications of current earnings for future earnings. Journal of Accounting and Economics 13, 305-340.

Bizjak, J., Lemmon, M., Whitby, R., 2009. Option backdating and board interlocks. Review of Financial Studies 22, 4821-4847.

Boehmer, E., Huszar, Z. R., Jordan, B. D., 2010. The good news in short interest. Journal of Financial Economics 96, 80-97.

Brown, S., Hillegeist, S. A., 2007. How disclosure quality affects the level of information asymmetry. Review of Accounting Studies 12, 433-477.

Campbell, J. Y., Ramadorai, T., Schwartz, A., 2009. Caught on tape: Institutional trading, stock returns, and earnings announcements. Journal of Financial Economics 92, 66-91.

Carhart, M. M., 1997. On persistence in mutual fund performance. Journal of Finance 52, 57-82.

Chiu, P.-C., Teoh, S. H., Tian, F., 2012. Board interlocks and earnings management contagion. The Accounting Review 88, 915-944. 
Christophe, S., Ferri, M., Angel, J., 2004. Short-selling prior to earnings announcements. Journal of Finance 59, 1845-1875.

Christophe, S., Ferri, M., Hsieh, J., 2010. Informed trading before analyst downgrades: Evidence from short sellers. Journal of Financial Economics 95, 85-106.

Chung, K. H., Elder, J., Kim, J.-C., 2010. Corporate governance and liquidity. Journal of Financial and Quantitative Analysis 45 (02), 265-291.

Cohen, L., Diether, K. B., Malloy, C. J., 2007. Supply and demand shifts in the shorting market. Journal of Finance 62, 2061-2096.

Cohen, L., Frazzini, A., Malloy, C., 2008. The small world of investing: Board connections and mutual fund returns. Journal of Political Economy 116, 951-979.

Cohen, L., Frazzini, A., Malloy, C., 2010. Sell side school ties. Journal of Financial Economics $65,1409-1437$.

Cohen, L., Lou, D., 2012. Complicated firms. Journal of Financial Economics 104, 383-400.

Cohen, L., Malloy, C., Pomorski, L., 2012. Decoding inside information. Journal of Finance 67, 1009-1043.

D’Avolio, G., 2002. The market for borrowing stock. Journal of Financial Economics 66, 271-306.

Desai, H., Krishnamurthy, S., Venkataraman, K., 2006. Do short sellers target firms with poor earnings quality? Evidence from earnings restatements. Review of Accounting Studies 11, 7190.

Easley, D., Kiefer, N. M., O'Hara, M., 1997. One day in the life of a very common stock. Review of Financial Studies 10, 805-835.

Engelberg, J., Reed, A., Ringgenberg, M., 2012. How are shorts informed? Short sellers, news, and information processing. Journal of Financial Economics 105, 260-278.

Faleye, O., Kovacs, T., Venkateswaran, A., 2014. Do better-connected CEOs innovate more? Journal of Financial and Quantitative Analysis 49, 1201-1225.

Fama, E. F., French, K. R., 1993. Common risk factors in the returns on stocks and bonds. Journal of Financial Economics 33, 3-56.

Fama, E. F., MacBeth, J., 1973. Risk, return, and equilibrium: Empirical tests. Journal of Political Economy 81, 607-636.

Fisman, D., Fisman, R. J., Galef, J., Khurana, R., Wang, Y., 2012. Estimating the value of connections to Vice-President Cheney. The BE Journal of Economic Analysis \& Policy 12 (3). 
Griffin, J. M., Harris, J. H., Topaloğlu, S., 2003. The dynamics of institutional and individual trading. Journal of Finance 58, 2285-2320.

Griffin, J. M., Shu, T., Topaloğlu, S., 2012. Examining the dark side of financial markets: Do institutions trade on information from investment bank connections? Review of Financial Studies 25 (7), 2155-2188.

Guedj, I., Barnea, A., 2009. Director networks, Working Paper, http://ssrn.com/abstract=966555.

Hirshleifer, D., Teoh, S., Yu, J., 2011. Short arbitrage, return asymmetry and the accrual anomaly. Review of Financial Studies 24, 2429-2461.

Hong, H., Lim, T., Stein, J. C., 2000. Bad news travels slowly: Size, analyst coverage and the profitability of momentum strategies. Journal of Finance 55, 265-295.

Jegadeesh, N., Titman, S., 1993. Returns to buying sinners and selling losers: Implications for stock market efficiency. Journal of Finance 48, 65-91.

Johnson, T. L., So, E. C., 2012. The option to stock volume ratio and future returns. Journal of Financial Economics 106 (2), 262-286.

Karpoff, J., Lou, X., 2010. Short sellers and financial misconduct. Journal of Finance 65, 1879_1913.

Keown, A. J., Pinkerton, J. M., 1981. Merger announcements and insider trading activity: An empirical investigation. Journal of Finance 36, 855-869.

Kothari, S. P., Shu, S., Wysocki, P. D., 2009. Do managers withhold bad news? Journal of Accounting Research 47 (1), 241-276.

Larcker, D. F., So, E. C., Wang, C. C. Y., 2013. Boardroom centrality and firm performance. Journal of Accounting and Economics 55, 225-250.

Leuz, C., Nanda, D., Wysocki, P. D., 2003. Earnings management and investor protection: An international comparison. Journal of Financial Economics 69 (3), 505-527.

McNichols, M., O’Brien, P. C., 1997. Self-selection and analyst coverage. Journal of Accounting and Economics 35, 167-199.

Molm, L. D., 2003. Theoretical comparisons of forms of exchange. Sociological Theory 1, 1-17.

Pan, J., Poteshman, A. M., 2006. The information in option volume for future stock prices. Review of Financial Studies 19, 871-908.

Pontiff, J., 2006. Costly arbitrage and the myth of idiosyncratic risk. Journal of Accounting and Economics 42, 35-52. 
Puckett, A., Yan, X. S., 2011. The interim trading skills of institutional investors. Journal of Finance $66,601-633$.

Steele, J. M., 1989. Models for managing secrets. Management Science 35, 240-248.

Stuart, T. E., Yim, S., 2010. Board interlocks and the propensity to be targeted in private equity transactions. Journal of Financial Economics 97, 174-189.

Wong, L. H., Gygax, A., Wang, P., 2015. Board interlocking network and the design of executive compensation packages. Social Networks 41, 85-100.

Zhang, X. F., 2006. Information uncertainty and stock returns. Journal of Finance 61, 105-137. 
Table 1

Variable Definitions.

Aggregate connections: Number of first-degree links for all directors on the board provided by BoardEx.

Analyst Surprise: Actual earnings per share minus median of most recent analyst forecasts scaled by stock price, obtained from $\mathrm{I} / \mathrm{B} / \mathrm{E} / \mathrm{S}$.

Number of Analysts: Number of analysts following the stock. The data on analysts are obtained from I/B/E/S. Board size: Total number of directors on the board of the company.

Book-to-Market: Ratio of book value to market value of equity.

Connectedness: Regression residual obtained from regressing the natural logarithm of aggregate connections on the natural logarithm of firm size, board size, firm age, number of analysts and institutional ownership.

Number of Employees: Number of employees provided by COMPUSTAT.

Firm age: Total number of years the company has been listed in CRSP.

Firm size: Market value of equity calculated as number of shares outstanding times the month-end share price. Illiquidity: Amihud (2002) illiquidity, absolute value of daily returns divided by dollar trading volume averaged over a month. We require at least 10 days of return-to-volume ratios per month to compute Illiquidity.

Institutional ownership: Sum of the holdings of all institutions for each stock in each quarter, divided by the number of shares outstanding obtained from CRSP. Stocks that have available return data but no reported institutional holdings are assumed to have zero institutional ownership.

Institutional OIB: Institutional trade order imbalance, measured as buyer minus seller initiated institutional trading over a week, normalized by total institutional trading in shares of a stock.

Leverage: Ratio of total long-term-debt to total assets.

Momentum: Cumulative return over the previous 12 months.

Option: Indicator equal to one if the firm has any exchange traded option (zero otherwise).

Option/Stock volume: Ratio of total option volume traded (put plus call) to total common stock traded.

PIN: Probability of Informed Trading measure constructed by Brown and Hillegeist (2007).

ROA: Return on Assets, previous year-end ratio of income before extraordinary items to total assets.

R\&D: Previous year-end ratio of research and development expenses to total assets. Missing research and development expenses are set to be 0 .

Return: Monthly stock return contemporaneous with short interest.

IVOL: Idiosyncratic return volatility, the standard deviation of residuals from the Fama-French (1993) model augmented with a momentum factor. We require at least 10 days of returns to compute IVOL.

Number of Segments: How many industry business segments (STYPE) the firm operated the previous year.

Sentiment: Aggregate difference in text-based positive and negative sentiment scores of firm-specific news.

Short interest: Total shares shorted divided by total shares outstanding.

Spread: Ask minus bid price divided by the mid point of this bid-ask spread, averaged over one year.

SUE: Standardized unexpected earnings, the standardized difference between reported earnings and expected earnings, assuming that earnings follows a seasonal random walk with a trend.

Turnover: The number of shares traded divided by the number of shares outstanding. 


\section{Table 2}

\section{Summary statistics.}

This table presents time-series averages of cross-sectional summary statistics for the short interest sample (Panel A), the Option/Stock volume sample (Panel B), and the institutional trading order imbalance (Institutional OIB) sample (Panel C). The sample consists of common stocks listed on AMEX, NASDAQ and NYSE with board data in the BoardEx database from January 2002 to December 2011. Connectedness is the residual obtained from a regression of the natural logarithm of aggregate connections on the natural logarithm of firm size, board size, firm age, number of analysts and institutional ownership. All other firm characteristics are as defined in Table 1.

\begin{tabular}{lrrrrr}
\hline \multicolumn{6}{c}{ Panel A: Summary statistics for the short interest sample } \\
\hline & Mean & Median & StdDev & Min & Max \\
\cline { 2 - 6 } Connectedness & 0.0011 & 0.0591 & 0.5192 & -1.7348 & 1.0987 \\
Aggregate Connections & 3,970 & 3,153 & 2,999 & 225 & 24,239 \\
Board size & 9.264 & 9.000 & 2.454 & 4.000 & 25.000 \\
Firm size & 6.936 & 1.624 & 20.901 & 0.014 & 300.395 \\
Short Interest & 0.049 & 0.035 & 0.056 & 0 & 0.815 \\
IVOL & 0.026 & 0.023 & 0.014 & 0.004 & 0.159 \\
Institutional ownership & 0.718 & 0.769 & 0.208 & 0.006 & 0.999 \\
Momentum & 0.160 & 0.085 & 0.522 & -0.818 & 6.535 \\
Turnover & 2.091 & 1.574 & 2.007 & 0.016 & 26.038 \\
Return & 0.011 & 0.006 & 0.115 & -0.466 & 0.959 \\
Book-to-Market & 0.761 & 0.505 & 1.904 & 0 & 45.718 \\
Illiquidity & 0.730 & 0.002 & 19.856 & 0 & 586.906 \\
Number of Analysts & 9.483 & 7.813 & 7.288 & 0 & 39.500 \\
Return on Assets & 0.021 & 0.042 & 0.152 & -1.771 & 0.454 \\
Leverage & 0.174 & 0.151 & 0.164 & 0 & 0.847 \\
Option & 0.798 & 1.000 & 0.393 & 0 & 1.000 \\
Number of Segments & 8.168 & 7.913 & 5.432 & 1 & 28.450 \\
R\&D & 0.038 & 0.000 & 0.075 & 0 & 0.710 \\
Firm Age & 24.743 & 17.294 & 19.243 & 1.858 & 81.125 \\
\# Firm / Month Observations & & 115,978 & & & \\
\hline
\end{tabular}




\begin{tabular}{lrrrrr}
\hline \multicolumn{5}{c}{ Panel B: Summary statistics for the Option/Stock volume sample } \\
\hline & Mean & Median & StdDev & Min & Max \\
\cline { 2 - 6 } Connectedness & 0.0003 & 0.0617 & 0.4908 & -1.5636 & 1.0158 \\
Aggregate Connection & 4,461 & 3,660 & 3,172 & 339 & 24,233 \\
Board size & 9.468 & 9.000 & 2.461 & 4.395 & 23.866 \\
Firm size & 8.907 & 2.465 & 23.972 & 0.063 & 300.842 \\
Option/Stock volume & 0.038 & 0.015 & 0.072 & 0 & 0.908 \\
IVOL & 0.025 & 0.022 & 0.013 & 0.005 & 0.130 \\
Institutional ownership & 0.763 & 0.795 & 0.164 & 0.076 & 0.999 \\
Momentum & 0.138 & 0.080 & 0.448 & -0.763 & 4.534 \\
Turnover & 2.335 & 1.780 & 2.040 & 0.160 & 23.700 \\
Return & 0.009 & 0.006 & 0.105 & -0.425 & 0.667 \\
Book-to-Market & 0.599 & 0.448 & 0.743 & 0.008 & 12.664 \\
Illiquidity & 0.735 & 0.001 & 20.023 & 0 & 548.178 \\
Number of Analysts & 11.416 & 10.000 & 7.233 & 0 & 39.454 \\
Return on Assets & 0.037 & 0.048 & 0.121 & -1.196 & 0.447 \\
Leverage & 0.176 & 0.159 & 0.160 & 0 & 0.803 \\
Number of Segments & 8.340 & 8.197 & 5.559 & 1 & 28.437 \\
R\&D & 0.038 & 0.002 & 0.068 & 0 & 0.578 \\
Firm Age & 26.200 & 18.732 & 20.326 & 1.868 & 81.099 \\
\# Firm / Month Observations & & 80,042 & & & \\
\hline
\end{tabular}

\begin{tabular}{lrrrrr}
\multicolumn{6}{c}{ Panel C: Summary statistics for the institutional trading order imbalance sample } \\
\cline { 2 - 6 } Connectedness & Mean & Median & STD & Min & Max \\
\cline { 2 - 6 } Aggregate connections & -0.0011 & 0.0586 & 0.5178 & -1.7468 & 1.0900 \\
Board size & 4,022 & 3,212 & 3,013 & 226 & 24,241 \\
Firm size & 9.316 & 9.000 & 2.447 & 4.030 & 24.976 \\
Institutional OIB & 7.182 & 1.710 & 21.283 & 0.020 & 300.382 \\
IVOL & 0.050 & 0.064 & 0.605 & -1 & 1.000 \\
Institutional Ownership & 0.023 & 0.019 & 0.017 & 0.001 & 0.197 \\
Momentum & 0.726 & 0.773 & 0.200 & 0.006 & 0.999 \\
Turnover & 0.156 & 0.085 & 0.502 & -0.808 & 6.168 \\
Return & 2.125 & 1.600 & 2.011 & 0.013 & 25.729 \\
Book-to-Market & 0.002 & 0.001 & 0.049 & -0.279 & 0.402 \\
Illiquidity & 0.725 & 0.499 & 1.305 & 0.005 & 25.154 \\
Number of Analysts & 0.075 & 0.002 & 1.147 & 0 & 30.918 \\
Return on Assets & 9.674 & 8.034 & 7.272 & 0 & 39.551 \\
Leverage & 0.026 & 0.043 & 0.145 & -1.675 & 0.452 \\
Option & 0.175 & 0.153 & 0.163 & 0 & 0.846 \\
Number of Segments & 0.806 & 1.000 & 0.384 & 0 & 1.000 \\
R\&D & 8.255 & 8.080 & 5.473 & 1 & 28.753 \\
Firm Age & 0.036 & 0.000 & 0.073 & 0 & 0.700 \\
\# Firm / Week Observations & 25.140 & 18.098 & 19.346 & 1 & 81.102 \\
\hline & & 512,509 & & & \\
\hline
\end{tabular}


Table 3

\section{Correlations.}

This table presents cross-sectional correlations among key variables in the short interest sample (Panel A), the option/stock volume sample (Panel B), and the institutional trading order imbalance sample (Panel C). The sample consists of common stocks listed on AMEX, NASDAQ and NYSE with board data in the BoardEx database from January 2002 to December 2011. Connectedness is the residual obtained from a regression of the natural logarithm of aggregate connections on the natural logarithm of firm size, board size, firm age, number of analysts and institutional ownership. All other firm characteristics are as defined in Table 1.

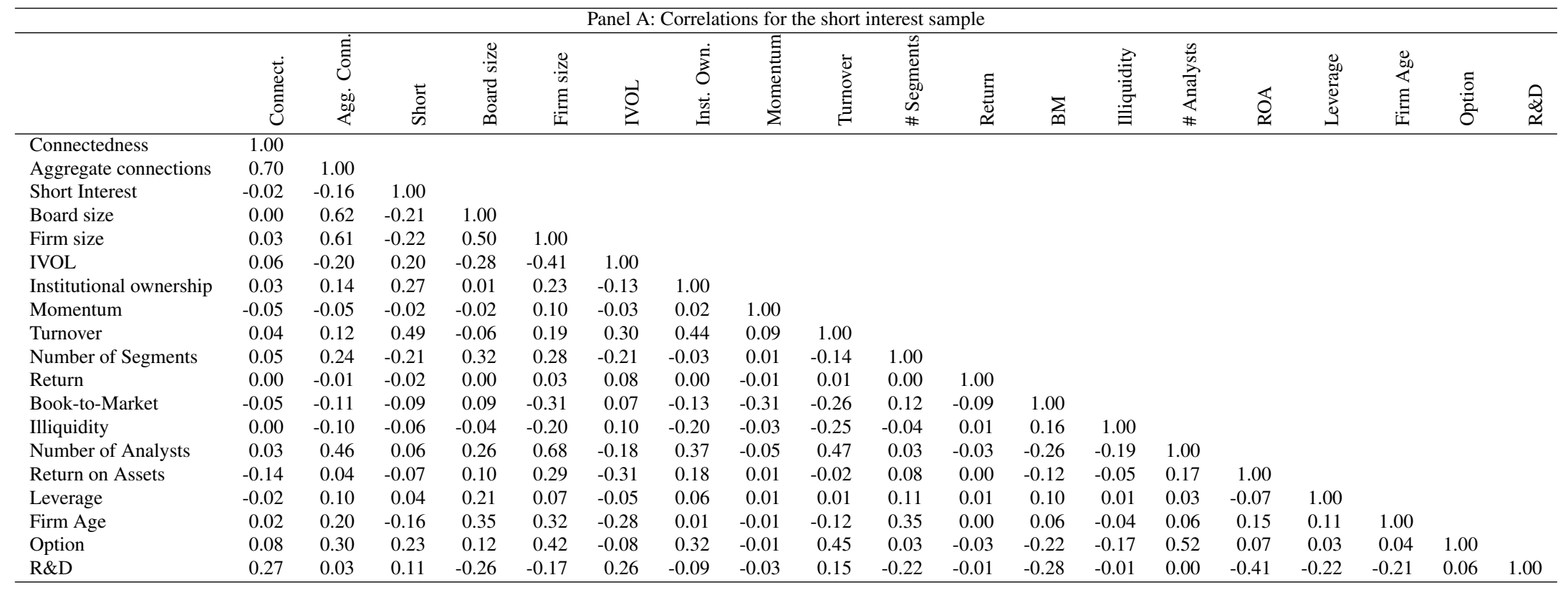




\begin{tabular}{|c|c|c|c|c|c|c|c|c|c|c|c|c|c|c|c|c|c|c|c|}
\hline \multicolumn{19}{|c|}{ Panel B: Correlations for the option volume/stock volume sample } & \\
\hline & 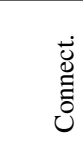 & 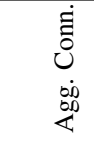 & 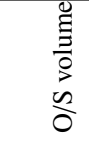 & 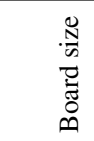 & $\begin{array}{l}\tilde{N} \\
\text { है } \\
\text { : }\end{array}$ & $\stackrel{\overrightarrow{0}}{\geq}$ & 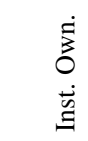 & $\dot{\Xi}^{\dot{\Sigma}}$ & 芦 & 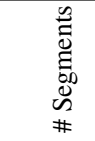 & 窇 & $\sum_{\infty}$ & 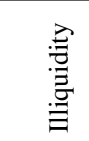 & 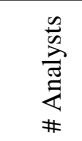 & 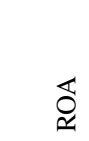 & 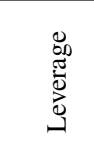 & 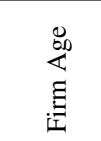 & 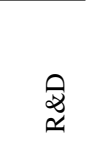 & \\
\hline Connectedness & 1.00 & & & & & & & & & & & & & & & & & & \\
\hline Aggregate connections & 0.70 & 1.00 & & & & & & & & & & & & & & & & & \\
\hline Option/Stock volume & 0.04 & 0.18 & 1.00 & & & & & & & & & & & & & & & & \\
\hline Board size & 0.00 & 0.65 & 0.02 & 1.00 & & & & & & & & & & & & & & & \\
\hline Firm size & 0.03 & 0.60 & 0.37 & 0.52 & 1.00 & & & & & & & & & & & & & & \\
\hline Institutional ownership & 0.03 & -0.02 & 0.07 & -0.10 & 0.01 & -0.03 & 1.00 & & & & & & & & & & & & \\
\hline Momentum & -0.06 & -0.04 & 0.12 & -0.01 & 0.12 & -0.04 & 0.06 & 1.00 & & & & & & & & & & & \\
\hline Turnover & 0.00 & -0.10 & 0.44 & -0.19 & -0.08 & 0.48 & 0.29 & 0.08 & 1.00 & & & & & & & & & & \\
\hline Number of Segments & 0.07 & 0.28 & -0.10 & 0.32 & 0.29 & -0.21 & -0.08 & 0.00 & -0.24 & 1.00 & & & & & & & & & \\
\hline Return & -0.01 & 0.00 & 0.03 & 0.01 & 0.05 & 0.03 & 0.02 & -0.02 & 0.00 & 0.00 & 1.00 & & & & & & & & \\
\hline Book-to-Market & -0.04 & -0.04 & -0.33 & 0.12 & -0.24 & 0.05 & -0.05 & -0.33 & -0.13 & 0.15 & -0.10 & 1.00 & & & & & & & \\
\hline Illiquidity & 0.07 & -0.19 & -0.17 & -0.21 & -0.41 & 0.24 & -0.19 & -0.12 & -0.21 & -0.10 & -0.02 & 0.14 & 1.00 & & & & & & \\
\hline Number of Analysts & 0.02 & 0.37 & 0.38 & 0.23 & 0.64 & -0.16 & 0.16 & -0.02 & 0.23 & 0.01 & -0.01 & -0.18 & -0.32 & 1.00 & & & & & \\
\hline Return on Assets & -0.14 & 0.03 & 0.07 & 0.07 & 0.29 & -0.27 & 0.11 & -0.01 & -0.07 & 0.05 & 0.00 & -0.17 & -0.21 & 0.18 & 1.00 & & & & \\
\hline Leverage & 0.00 & 0.10 & -0.11 & 0.20 & 0.06 & -0.06 & 0.02 & 0.02 & -0.01 & 0.10 & 0.01 & 0.11 & -0.07 & 0.00 & -0.13 & 1.00 & & & \\
\hline \multicolumn{20}{|c|}{ Panel C: Correlations for the institutional trading sample } \\
\hline & $\begin{array}{l}\dot{0} \\
\dot{\Xi} \\
\dot{0}\end{array}$ & $\begin{array}{l}\dot{\Xi} \\
\dot{0} \\
0.0 \\
00 \\
0\end{array}$ & $\begin{array}{l}\mathscr{0} \\
\dot{0} \\
\dot{0}\end{array}$ & 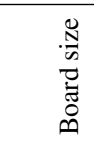 & 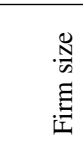 & $\stackrel{\overrightarrow{0}}{\geq}$ & 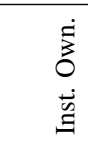 & $\dot{\Xi}^{\dot{\Sigma}}$ & 离 & 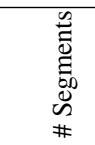 & 吾 & $\sum_{m}$ & 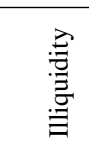 & 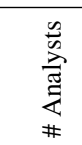 & $\begin{array}{l}\mathbb{O} \\
\mathbb{N}\end{array}$ & 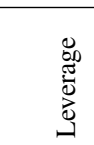 & $\begin{array}{l}\stackrel{8}{ \pm} \\
\Xi \\
\text { 江 }\end{array}$ & مَ & $\begin{array}{l}\text { के } \\
\approx\end{array}$ \\
\hline Connectedness & 1.00 & & & & & & & & & & & & & & & & & & \\
\hline Aggregate connections & 0.71 & 1.00 & & & & & & & & & & & & & & & & & \\
\hline Institutional OIB & 0.00 & -0.04 & 1.00 & & & & & & & & & & & & & & & & \\
\hline Board size & 0.01 & 0.61 & -0.02 & 1.00 & & & & & & & & & & & & & & & \\
\hline Firm size & 0.04 & 0.60 & -0.05 & 0.49 & 1.00 & & & & & & & & & & & & & & \\
\hline IVOL & 0.04 & -0.14 & 0.01 & -0.20 & -0.28 & 1.00 & & & & & & & & & & & & & \\
\hline Institutional ownership & 0.04 & 0.11 & -0.04 & -0.03 & 0.17 & -0.06 & 1.00 & & & & & & & & & & & & \\
\hline Momentum & -0.05 & -0.06 & 0.02 & -0.02 & 0.09 & -0.01 & 0.03 & 1.00 & & & & & & & & & & & \\
\hline Turnover & 0.05 & 0.11 & -0.04 & -0.09 & 0.16 & 0.21 & 0.43 & 0.08 & 1.00 & & & & & & & & & & \\
\hline Number of Segments & 0.05 & 0.24 & -0.01 & 0.32 & 0.26 & -0.14 & -0.06 & 0.00 & -0.17 & 1.00 & & & & & & & & & \\
\hline Return & 0.00 & -0.01 & 0.13 & 0.00 & 0.01 & 0.10 & 0.00 & 0.02 & 0.00 & 0.00 & 1.00 & & & & & & & & \\
\hline Book-to-Market & -0.05 & -0.10 & 0.00 & 0.11 & -0.31 & 0.04 & -0.14 & -0.32 & -0.26 & 0.14 & -0.04 & 1.00 & & & & & & & \\
\hline Illiquidity & -0.01 & -0.11 & 0.01 & -0.04 & -0.22 & 0.08 & -0.21 & -0.04 & -0.29 & -0.03 & 0.00 & 0.19 & 1.00 & & & & & & \\
\hline Number of Analysts & 0.03 & 0.44 & -0.06 & 0.23 & 0.67 & -0.11 & 0.33 & -0.05 & 0.46 & 0.00 & -0.01 & -0.27 & -0.21 & 1.00 & & & & & \\
\hline Option & 0.09 & 0.28 & -0.04 & 0.10 & 0.38 & -0.04 & 0.29 & -0.02 & 0.44 & 0.00 & -0.01 & -0.22 & -0.19 & 0.51 & 0.05 & 0.03 & 0.00 & 1.00 & \\
\hline$R \& D$ & 0.26 & 0.04 & 0.02 & -0.26 & -0.15 & 0.18 & -0.07 & -0.02 & 0.17 & -0.21 & -0.01 & -0.28 & 0.00 & 0.02 & -0.40 & -0.21 & -0.21 & 0.08 & 1.00 \\
\hline
\end{tabular}




\section{Table 4}

Board connectedness, informed trading, and stock returns: Portfolio approach.

This table presents Fama-French four-factor alphas $(\alpha \mathrm{s})$ from portfolios formed as follows. Each month we first rank stocks into three groups by Connectedness. Then the stocks are sorted into quintiles on the basis of three informed trading variables: monthly short interest (Panel A); monthly option/stock volume (Panel B); and weekly institutional trade order imbalance, Institutional OIB (Panel C). Connectedness is the residual obtained from a regression of the natural logarithm of aggregate connections on the natural logarithm of firm size, board size, firm age, number of analysts and institutional ownership. In Panels A and B (Panel C), portfolios are rebalanced every month (week). The sample consists of common stocks listed on AMEX, NASDAQ and NYSE with board data in the BoardEx database from January 2002 to December 2011. Newey-West $t$-statistics, in parentheses, of the difference between the highest and lowest quintiles of the informed trading variables, are reported below the coefficient estimates. Superscripts $a, b$, and $c$ indicate significance at the $1 \%, 5 \%$, and $10 \%$ levels, respectively.

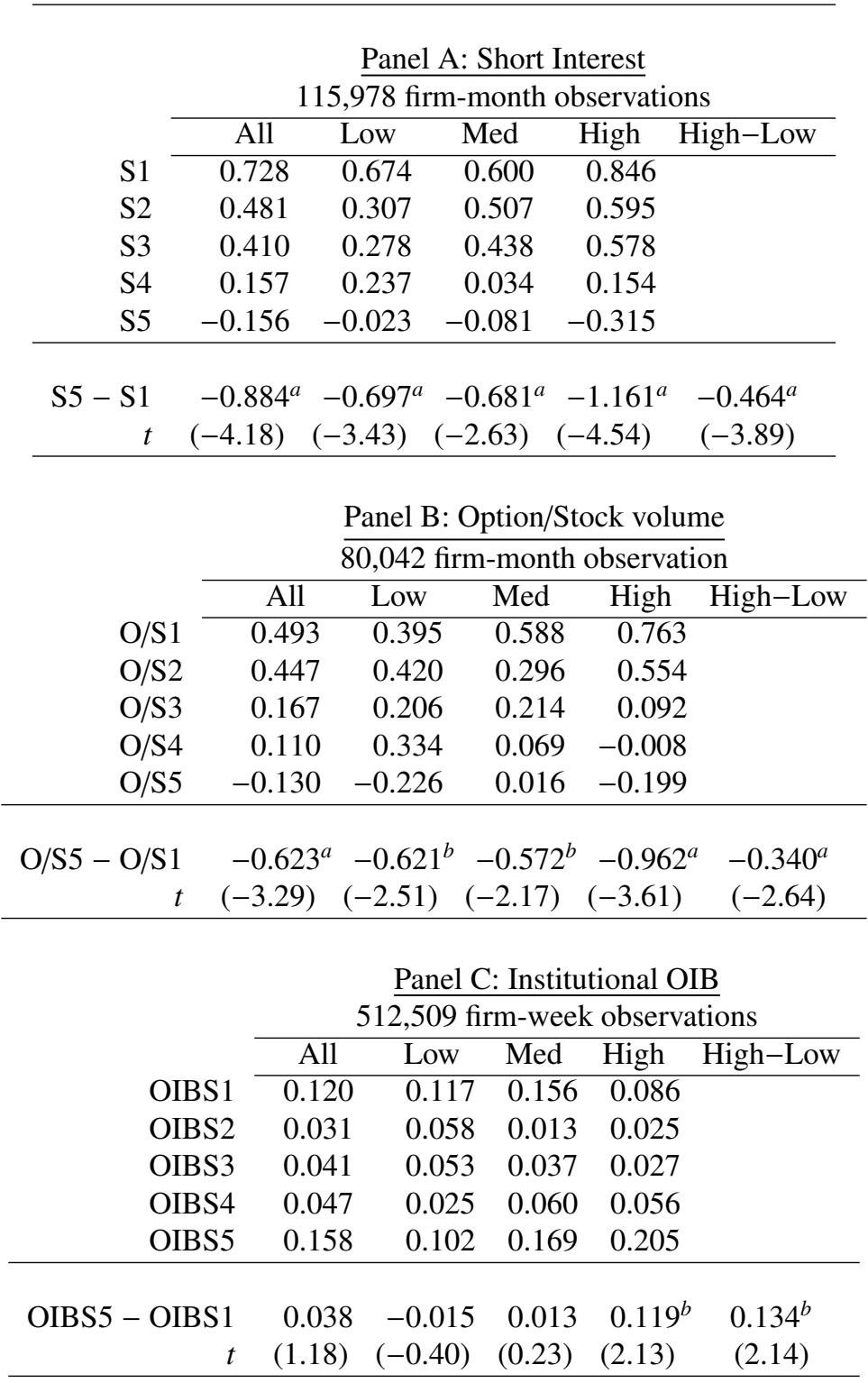




\section{Table 5}

Board Connectedness, informed trading, and stock returns: Multivariate regressions.

This table presents the results from Fama-MacBeth regressions of stock returns on informed trading variables, connectedness, and other firm characteristics. The informed trading variables are monthly short interest, Option/Stock volume, and institutional trading order imbalance (Institutional OIB) in columns (1), (2) and (3), respectively. Decile ranks of these variables are used in the regressions. Connectedness is the residual obtained from a regression of the natural logarithm of aggregate connections on the natural logarithm of firm size, board size, firm age, number of analysts and institutional ownership. The dependent variables are monthly future stock returns in columns (1) and (2), and weekly future stock returns in column (3). The firm characteristics are as defined in Table 1. The sample consists of common stocks listed on AMEX, NASDAQ and NYSE with board data in the BoardEx database from January 2002 to December 2011. Newey-West $t$-statistics, in parentheses, are reported below the coefficient estimates. Superscripts $a, b$, and $c$ indicate significance at the $1 \%, 5 \%$, and $10 \%$ levels, respectively. Industry fixed effects are included in all specifications.

\begin{tabular}{|c|c|c|c|}
\hline & (1) & (2) & (3) \\
\hline Short Interest & $\begin{array}{l}-1.062^{a} \\
(-4.42)\end{array}$ & & \\
\hline Short Interest $\times$ Connectedness & $\begin{array}{l}-0.395^{a} \\
(-2.81)\end{array}$ & & \\
\hline Option/Stock volume & & $\begin{array}{l}-0.636^{a} \\
(-3.14)\end{array}$ & \\
\hline Option/Stock volume $\times$ Connectedness & & $\begin{array}{l}-0.513^{a} \\
(-2.59)\end{array}$ & \\
\hline Institutional OIB & & & $\begin{array}{l}0.059^{b} \\
(2.27)\end{array}$ \\
\hline Institutional OIB $\times$ Connectedness & & & $\begin{array}{l}0.094^{b} \\
(2.10)\end{array}$ \\
\hline Connectedness & $\begin{array}{l}0.319^{a} \\
(2.72)\end{array}$ & $\begin{array}{l}0.241^{b} \\
(2.15)\end{array}$ & $\begin{array}{c}-0.026 \\
(-0.90)\end{array}$ \\
\hline Firm size & $\begin{array}{l}-0.357^{a} \\
(-3.37)\end{array}$ & $\begin{array}{l}-0.136^{b} \\
(-2.03)\end{array}$ & $\begin{array}{l}-0.135^{a} \\
(-3.94)\end{array}$ \\
\hline Return & $\begin{array}{l}-1.975^{a} \\
(-3.39)\end{array}$ & $\begin{array}{l}-2.338^{a} \\
(-2.72)\end{array}$ & $\begin{array}{l}-2.395^{a} \\
(-4.49)\end{array}$ \\
\hline Institutional ownership & $\begin{array}{c}0.065 \\
(0.19)\end{array}$ & $\begin{array}{r}0.057 \\
(0.12)\end{array}$ & $\begin{array}{r}0.145 \\
(1.18)\end{array}$ \\
\hline Firm Age & $\begin{array}{c}0.076 \\
(1.43)\end{array}$ & $\begin{array}{c}-0.040 \\
(-0.84)\end{array}$ & $\begin{array}{c}0.056^{a} \\
(2.80)\end{array}$ \\
\hline Book-to-Market & $\begin{array}{c}0.039 \\
(0.36)\end{array}$ & $\begin{array}{r}0.010 \\
(0.08)\end{array}$ & $\begin{array}{l}-0.515^{a} \\
(-7.41)\end{array}$ \\
\hline Leverage & $\begin{array}{c}0.468 \\
(1.15)\end{array}$ & $\begin{array}{r}0.327 \\
(0.69)\end{array}$ & $\begin{array}{c}-0.163 \\
(-1.54)\end{array}$ \\
\hline Number of Analysts & $\begin{array}{l}-0.019 \\
(-0.19)\end{array}$ & $\begin{array}{l}0.131 \\
(0.88)\end{array}$ & $\begin{array}{l}-0.028 \\
(-0.98)\end{array}$ \\
\hline$R \& D$ & $\begin{array}{c}0.915 \\
(0.55)\end{array}$ & $\begin{array}{l}2.996^{c} \\
(1.83)\end{array}$ & $\begin{array}{l}-2.364 \\
(-5.56)\end{array}$ \\
\hline Turnover & $\begin{array}{l}0.277^{a} \\
(3.85)\end{array}$ & $\begin{array}{c}0.112 \\
(0.95)\end{array}$ & $\begin{array}{r}0.027 \\
(0.37)\end{array}$ \\
\hline Illiquidity & $\begin{array}{l}0.304^{c} \\
(1.69)\end{array}$ & $\begin{array}{c}9.108 \\
(0.97)\end{array}$ & $\begin{array}{c}0.192^{b} \\
(2.56)\end{array}$ \\
\hline Option & $\begin{array}{l}0.008 \\
(0.13)\end{array}$ & & $\begin{array}{l}-0.083^{a} \\
(-2.67)\end{array}$ \\
\hline Return on Assets & $\begin{array}{l}1.068^{c} \\
(1.82)\end{array}$ & $\begin{array}{c}0.663 \\
(1.27)\end{array}$ & $\begin{array}{l}-0.585^{b} \\
(-2.46)\end{array}$ \\
\hline Momentum & $\begin{array}{l}-0.572 \\
(-0.87)\end{array}$ & $\begin{array}{c}-0.824 \\
(-1.63)\end{array}$ & $\begin{array}{l}-0.477^{b} \\
(-2.45)\end{array}$ \\
\hline Number of Segments & $\begin{array}{l}-0.001 \\
(-0.13)\end{array}$ & $\begin{array}{r}0.007 \\
(0.78)\end{array}$ & $\begin{array}{c}0.012 \\
(7.01)\end{array}$ \\
\hline IVOL & $\begin{array}{l}-8.932 \\
(-1.27)\end{array}$ & $\begin{array}{c}-10.246^{c} \\
(-1.78)\end{array}$ & $\begin{array}{c}0.199 \\
(0.14)\end{array}$ \\
\hline Intercept & $\begin{array}{l}5.808^{a} \\
(3.50)\end{array}$ & $\begin{array}{l}2.533^{a} \\
(2.87)\end{array}$ & $\begin{array}{l}1.418^{a} \\
(3.42)\end{array}$ \\
\hline Adj. $R^{2}$ & $9.2 \%$ & $15.3 \%$ & $12.8 \%$ \\
\hline
\end{tabular}




\section{Table 6}

Board connectedness, informed traders, and earnings surprises.

This table presents the results from Fama-MacBeth regressions of earnings surprises on informed trading variables, connectedness, and other firm characteristics. The informed trading variables are monthly short interest, Option/Stock volume, and institutional trading order imbalance (Institutional OIB). Decile ranks of these variables are used in the regressions. Connectedness is the residual obtained from a regression of the natural logarithm of aggregate connections on the natural logarithm of firm size, board size, firm age, number of analysts and institutional ownership. The dependent variables are three different measures of earnings surprise: Unexpected Earnings, Standardized Unexpected Earnings (SUE) and Analyst Surprise. Unexpected Earnings is calculated as $\left(E P S_{i, q}-E P S_{i, q-4}\right) / P_{i, q-4}$, where $E P S_{i, q}$ and $E P S_{i, q-4}$ are earnings per share before extraordinary items for firm $i$ in quarters $q$ and $q-4$, respectively, and $P_{i q-4}$ is the stock price in quarter $q-4$. SUE is calculated as $\left(E P S_{i, q}-E P S_{i, q-4}-\mu_{i, q}\right) / \sigma_{i, q}$, where $\mu_{i, q}$ and $\sigma_{i, q}$ are the mean and standard deviations of earnings changes $\left(E P S_{i, q}-E P S_{i, q-4}\right)$ in the previous eight quarters, respectively. Analyst surprise is the difference between actual earnings per share (EPS) reported in $\mathrm{I} / \mathrm{B} / \mathrm{E} / \mathrm{S}$ in quarter $\mathrm{q}$, and the median of the most recent forecasts made by analysts following the firm over the 90 days prior to the earnings announcement; this difference is then scaled by $P_{i, q-4}$. The sample consists of common stocks listed on AMEX, NASDAQ and NYSE with board data in the BoardEx database from January 2002 to December 2011. Industry fixed effects are included in all specifications. Other controls are the same as those used in Table 5 and are as defined in Table 1. Newey-West $t$-statistics, in parentheses, are reported below the coefficient estimates. Superscripts $a, b$, and $c$ indicate significance at the $10 \%, 5 \%$, and $1 \%$ levels, respectively.

\begin{tabular}{|c|c|c|c|c|c|c|c|c|c|}
\hline & \multicolumn{3}{|c|}{ Unexpected Earnings } & \multicolumn{3}{|c|}{ SUE } & \multicolumn{3}{|c|}{ Analyst Surprise } \\
\hline & (1) & (2) & (3) & (4) & (5) & (6) & (7) & (8) & (9) \\
\hline Short Interest & $\begin{array}{l}-0.659^{a} \\
(-3.00)\end{array}$ & & & $\begin{array}{c}0.902 \\
(0.56)\end{array}$ & & & $\begin{array}{l}-0.028^{a} \\
(-2.64)\end{array}$ & & \\
\hline Short Interest $\times$ Connectedness & $\begin{array}{l}-0.681^{b} \\
(-2.52)\end{array}$ & & & $\begin{array}{l}-5.640^{a} \\
(-3.07)\end{array}$ & & & $\begin{array}{c}0.004 \\
(0.31)\end{array}$ & & \\
\hline Option/Stock volume & & $\begin{array}{l}-0.141^{b} \\
(-2.44)\end{array}$ & & & $\begin{array}{c}1.734 \\
(0.91)\end{array}$ & & & $\begin{array}{l}-0.008 \\
(-0.94)\end{array}$ & \\
\hline Option/Stock volume $\times$ Connectedness & & $\begin{array}{l}-0.439^{a} \\
(-3.69)\end{array}$ & & & $\begin{array}{l}-4.884^{b} \\
(-2.26)\end{array}$ & & & $\begin{array}{l}-0.046^{b} \\
(-1.99)\end{array}$ & \\
\hline Institutional OIB & & & $\begin{array}{c}0.059 \\
(0.39)\end{array}$ & & & $\begin{array}{l}5.858^{a} \\
(3.11)\end{array}$ & & & $\begin{array}{c}0.065^{\circ} \\
(4.67)\end{array}$ \\
\hline Institutional OIB $\times$ Connectedness & & & $\begin{array}{c}0.259 \\
(1.42)\end{array}$ & & & $\begin{array}{c}-0.964 \\
(-0.26)\end{array}$ & & & $\begin{array}{c}0.041^{c} \\
(1.78)\end{array}$ \\
\hline Connectedness & $\begin{array}{l}0.522^{b} \\
(1.95)\end{array}$ & $\begin{array}{c}0.290^{b} \\
(2.41)\end{array}$ & $\begin{array}{c}0.184 \\
(0.92)\end{array}$ & $\begin{array}{c}1.506 \\
(1.29)\end{array}$ & $\begin{array}{c}2.034 \\
(1.24)\end{array}$ & $\begin{array}{l}-0.199 \\
(-0.10)\end{array}$ & $\begin{array}{l}0.008^{b} \\
(0.76)\end{array}$ & $\begin{array}{c}0.044 \\
(2.39)\end{array}$ & $\begin{array}{l}-0.010 \\
(-0.60)\end{array}$ \\
\hline Lag Surprise & $\begin{array}{l}1.277 \\
(1.08)\end{array}$ & $\begin{array}{c}2.665 \\
(1.48)\end{array}$ & $\begin{array}{l}3.449^{b} \\
(2.16)\end{array}$ & $\begin{array}{l}27.065^{a} \\
(18.39)\end{array}$ & $\begin{array}{c}26.988 \\
(17.87)\end{array}$ & $\begin{array}{c}0.032^{a} \\
(0.07)\end{array}$ & $\begin{array}{l}3.942^{a} \\
(6.24)\end{array}$ & $\begin{array}{c}5.703 \\
(7.23)\end{array}$ & $\begin{array}{r}0.000 \\
(-0.06)\end{array}$ \\
\hline Other controls & Yes & Yes & Yes & Yes & Yes & Yes & Yes & Yes & Yes \\
\hline Adj. R 2 & $15.0 \%$ & $15.7 \%$ & $16.7 \%$ & $18.81 \%$ & $19.91 \%$ & $17.76 \%$ & $14.15 \%$ & $14.12 \%$ & $9.99 \%$ \\
\hline
\end{tabular}


Table 7

Board connectedness, informed traders, and firm-specific news sentiment.

This table presents the results from Fama-MacBeth regressions of news sentiment on informed trading variables, connectedness, and other firm characteristics. The informed trading variables are monthly short interest, Option/Stock volume, and institutional trading order imbalance (Institutional OIB) in columns (1), (2) and (3), respectively. Decile ranks of these variables are used in the regressions. Connectedness is the residual obtained from a regression of the natural logarithm of aggregate connections on the natural logarithm of firm size, board size, firm age, number of analysts and institutional ownership. The dependent variable is the difference between positive and negative news sentiment of firm-specific news from Thomson Reuters News Analytics. The sample consists of common stocks listed on AMEX, NASDAQ and NYSE with board data in the BoardEx database from January 2002 to December 2011, and news sentiment data from Thomson Reuters. Industry fixed effects are included in all specifications. Other firm characteristics are as defined in Table 1. Newey-West $t$-statistics, in parentheses, are reported below the coefficient estimates. Superscripts $a, b$, and $c$ indicate significance at the $10 \%, 5 \%$, and $1 \%$ levels, respectively.

\begin{tabular}{|c|c|c|c|}
\hline & (1) & (2) & (3) \\
\hline Short Interest & $\begin{array}{l}-3.162^{a} \\
(-5.40)\end{array}$ & & \\
\hline Short Interest $\times$ Connectedness & $\begin{array}{l}-1.445^{b} \\
(-2.32)\end{array}$ & & \\
\hline Option/Stock volume & & $\begin{array}{l}-1.461^{a} \\
(-5.22)\end{array}$ & \\
\hline Option/Stock volume $\times$ Connectedness & & $\begin{array}{l}-1.639^{a} \\
(-3.07)\end{array}$ & \\
\hline Institutional OIB & & & $\begin{array}{r}0.260 \\
(0.97)\end{array}$ \\
\hline Institutional OIB $\times$ Connectedness & & & $\begin{array}{l}1.242^{b} \\
(2.26)\end{array}$ \\
\hline Connectedness & $\begin{array}{c}2.213^{a} \\
(4.91)\end{array}$ & $\begin{array}{l}1.770^{a} \\
(6.95)\end{array}$ & $\begin{array}{l}1.042^{b} \\
(2.13)\end{array}$ \\
\hline Firm Size & $\begin{array}{l}-0.433^{a} \\
(-5.45)\end{array}$ & $\begin{array}{l}0.137^{c} \\
(1.75)\end{array}$ & $\begin{array}{l}1.071^{a} \\
(5.60)\end{array}$ \\
\hline Return & $\begin{array}{l}4.749^{a} \\
(3.00)\end{array}$ & $\begin{array}{l}8.399^{a} \\
(3.75)\end{array}$ & $\begin{array}{l}21.379^{a} \\
(6.05)\end{array}$ \\
\hline Institutional ownership & $\begin{array}{l}1.526 \\
(0.95)\end{array}$ & $\begin{array}{c}0.462 \\
(0.28)\end{array}$ & $\begin{array}{l}2.599^{a} \\
(3.22)\end{array}$ \\
\hline Firm Age & $\begin{array}{c}0.198 \\
(1.59)\end{array}$ & $\begin{array}{l}0.386^{b} \\
(2.41)\end{array}$ & $\begin{array}{c}0.219 \\
(1.26)\end{array}$ \\
\hline Book-to-Market & $\begin{array}{l}-1.238^{a} \\
(-3.61)\end{array}$ & $\begin{array}{l}-0.926^{b} \\
(-2.08)\end{array}$ & $\begin{array}{l}-0.976^{a} \\
(-4.35)\end{array}$ \\
\hline Leverage & $\begin{array}{l}-2.460^{a} \\
(-6.56)\end{array}$ & $\begin{array}{l}-1.310^{c} \\
(-1.68)\end{array}$ & $\begin{array}{l}-0.226 \\
(-0.31)\end{array}$ \\
\hline Number of Analysts & $\begin{array}{l}0.398^{b} \\
(2.48)\end{array}$ & $\begin{array}{l}-0.080 \\
(-0.15)\end{array}$ & $\begin{array}{r}0.437 \\
(1.09)\end{array}$ \\
\hline$R \& D$ & $\begin{array}{l}13.932^{a} \\
(4.30)\end{array}$ & $\begin{array}{l}15.167^{a} \\
(2.12)\end{array}$ & $\begin{array}{l}14.489^{a} \\
(5.43)\end{array}$ \\
\hline Turnover & $\begin{array}{l}0.715^{b} \\
(2.53)\end{array}$ & $\begin{array}{c}0.217 \\
(1.36)\end{array}$ & $\begin{array}{l}-0.520 \\
(-1.42)\end{array}$ \\
\hline Illiquidity & $\begin{array}{c}3.302 \\
(1.18)\end{array}$ & $\begin{array}{c}37.669 \\
(0.75)\end{array}$ & $\begin{array}{c}0.100 \\
(0.01)\end{array}$ \\
\hline Option & $\begin{array}{c}2.479^{a} \\
(11.26)\end{array}$ & & $\begin{array}{l}-0.855^{b} \\
(-1.66)\end{array}$ \\
\hline Return on Assets & $\begin{array}{c}1.284 \\
(1.49)\end{array}$ & $\begin{array}{l}4.318^{b} \\
(2.19)\end{array}$ & $\begin{array}{l}3.253^{a} \\
(3.10)\end{array}$ \\
\hline Momentum & $\begin{array}{l}2.681^{a} \\
(3.47)\end{array}$ & $\begin{array}{c}2.949^{a} \\
(4.53)\end{array}$ & $\begin{array}{l}2.280^{a} \\
(3.76)\end{array}$ \\
\hline Number of Segments & $\begin{array}{c}0.022 \\
(1.46)\end{array}$ & $\begin{array}{c}-0.013 \\
(-0.77)\end{array}$ & $\begin{array}{c}0.060^{b} \\
(2.53)\end{array}$ \\
\hline IVOL & $\begin{array}{l}-60.29^{a} \\
(-4.44)\end{array}$ & $\begin{array}{l}-47.78 \\
(-1.46)\end{array}$ & $\begin{array}{l}-46.31^{a} \\
(-7.10)\end{array}$ \\
\hline Lag_NEWS & $\begin{array}{r}24.98^{a} \\
(49.69)\end{array}$ & $\begin{array}{r}25.98^{a} \\
(36.88)\end{array}$ & $\begin{array}{r}12.10^{a} \\
(18.38)\end{array}$ \\
\hline Intercept & $\begin{array}{l}15.582^{a} \\
(7.53)\end{array}$ & $\begin{array}{l}9.323^{a} \\
(3.01)\end{array}$ & $\begin{array}{l}-9.292^{a} \\
(-3.82)\end{array}$ \\
\hline Adj. $R^{2}$ & $15.3 \%$ & $16.6 \%$ & $7.4 \%$ \\
\hline
\end{tabular}


Table 8

Board Connectedness, informed trading, and stock returns: Alternative explanations.

This table presents the results from Fama-MacBeth regressions of stock returns on informed trading variables, connectedness, and other firm characteristics, in which we control for family firm status (Panel A) and number of employees (Panel B). Connectedness is the residual obtained from a regression of the natural logarithm of aggregate connections on the natural logarithm of firm size, board size, firm age, number of analysts and institutional ownership. The dependent variables are monthly future stock returns in columns (1) - (4), and weekly future stock returns in columns (5) and (6). Family firm is as defined as in Anderson et al. (2012). Outsider is the ratio of outside directors to board size. Asset Tangibility is defined as the ratio Property, Plants, and Equipment (PPE) to total assets. The sample consists of common stocks listed on AMEX, NASDAQ and NYSE with board data in the BoardEx database from January 2002 to December 2011. Industry fixed effects and other control variables that are identical to those included in Table 5 (as defined in Table 1) are included in all specifications. Newey-West $t$-statistics, in parentheses, are reported below the coefficient estimates. Superscripts $a, b$, and $c$ indicate significance at the $1 \%, 5 \%$, and $10 \%$ levels, respectively.

\begin{tabular}{|c|c|c|c|c|c|c|}
\hline \multicolumn{7}{|c|}{ Panel A: Controlling for family firm status } \\
\hline & (1) & $(2)$ & (3) & (4) & (5) & (6) \\
\hline Short Interest & $\begin{array}{l}-0.427 \\
(-1.57)\end{array}$ & $\begin{array}{c}-0.392 \\
(-1.48)\end{array}$ & & & & \\
\hline Short Interest $\times$ Connectedness & & $\begin{array}{l}-0.428^{a} \\
(-4.70)\end{array}$ & & & & \\
\hline Option/Stock volume & & & $\begin{array}{l}-0.772^{a} \\
(-4.52)\end{array}$ & $\begin{array}{l}-0.767^{a} \\
(-4.48)\end{array}$ & & \\
\hline Option/Stock volume $\times$ Connectedness & & & & $\begin{array}{l}-0.471^{b} \\
(-1.98)\end{array}$ & & \\
\hline Institutional OIB & & & & & $\begin{array}{c}0.099^{b} \\
(2.47)\end{array}$ & $\begin{array}{c}0.091^{b} \\
(2.34)\end{array}$ \\
\hline Institutional OIB $\times$ Connectedness & & & & & & $\begin{array}{c}0.107^{b} \\
(2.49)\end{array}$ \\
\hline Connectedness & & $\begin{array}{c}0.250^{a} \\
(2.92)\end{array}$ & & $\begin{array}{c}0.195^{c} \\
(1.93)\end{array}$ & & $\begin{array}{l}-0.071^{a} \\
(-2.59)\end{array}$ \\
\hline Family firm & $\begin{array}{c}-0.124 \\
(-0.87)\end{array}$ & $\begin{array}{r}-0.082 \\
(-0.64)\end{array}$ & $\begin{array}{c}-0.367 \\
(-1.52)\end{array}$ & $\begin{array}{c}-0.362 \\
(-1.50)\end{array}$ & $\begin{array}{c}0.031 \\
(0.93)\end{array}$ & $\begin{array}{c}0.019 \\
(0.61)\end{array}$ \\
\hline Short Interest $\times$ Family firm & $\begin{array}{c}-0.155 \\
(-1.55)\end{array}$ & $\begin{array}{l}-0.226^{c} \\
(-1.88)\end{array}$ & & & & \\
\hline Option/Stock volume $\times$ Family firm & & & $\begin{array}{c}0.350 \\
(1.26)\end{array}$ & $\begin{array}{c}0.341 \\
(1.26)\end{array}$ & & \\
\hline Institutional OIB $\times$ Family firm & & & & & $\begin{array}{c}-0.016 \\
(-0.41)\end{array}$ & $\begin{array}{c}0.006 \\
(0.12)\end{array}$ \\
\hline Other controls & Yes & Yes & Yes & Yes & Yes & Yes \\
\hline Adj. $R^{2}$ & $6.19 \%$ & $6.30 \%$ & $7.14 \%$ & $7.33 \%$ & $5.49 \%$ & $5.64 \%$ \\
\hline
\end{tabular}




\begin{tabular}{|c|c|c|c|c|c|c|}
\hline \multicolumn{7}{|c|}{ Panel B: Controlling for number of outside directors } \\
\hline & (1) & (2) & (3) & (4) & (5) & (6) \\
\hline Short Interest & $\begin{array}{l}-1.305^{a} \\
(-4.77)\end{array}$ & $\begin{array}{l}-1.237^{a} \\
(-4.62)\end{array}$ & & & & \\
\hline Short Interest $\times$ Connectedness & & $\begin{array}{l}-0.431^{a} \\
(-2.87)\end{array}$ & & & & \\
\hline Option/Stock volume & & & $\begin{array}{l}-1.279^{a} \\
(-2.63)\end{array}$ & $\begin{array}{l}-1.197^{b} \\
(-2.25)\end{array}$ & & \\
\hline Option/Stock volume $\times$ Connectedness & & & & $\begin{array}{l}-0.411^{c} \\
(-1.70)\end{array}$ & & \\
\hline Institutional OIB & & & & & $\begin{array}{c}0.063 \\
(1.22)\end{array}$ & $\begin{array}{c}0.040 \\
(0.80)\end{array}$ \\
\hline Institutional OIB $\times$ Connectedness & & & & & & $\begin{array}{l}0.107^{b} \\
(2.46)\end{array}$ \\
\hline Connectedness & & $\begin{array}{l}0.309^{a} \\
(2.58)\end{array}$ & & $\begin{array}{l}0.214^{c} \\
(1.95)\end{array}$ & & $\begin{array}{l}-0.037 \\
(-1.32)\end{array}$ \\
\hline Outsider & $\begin{array}{c}-0.254 \\
(-0.59)\end{array}$ & $\begin{array}{l}-0.058 \\
(-0.14)\end{array}$ & $\begin{array}{l}-1.718^{a} \\
(-2.86)\end{array}$ & $\begin{array}{l}-1.499^{b} \\
(-2.14)\end{array}$ & $\begin{array}{c}-0.054 \\
(-0.27)\end{array}$ & $\begin{array}{l}-0.095 \\
(-0.49)\end{array}$ \\
\hline Short Interest $\times$ Outsider & $\begin{array}{c}1.601 \\
(1.22)\end{array}$ & $\begin{array}{c}1.339 \\
(0.99)\end{array}$ & & & & \\
\hline Option/Stock volume $\times$ Outsider & & & $\begin{array}{l}3.742^{b} \\
(2.06)\end{array}$ & $\begin{array}{r}3.239 \\
(1.55)\end{array}$ & & \\
\hline Institutional OIB $\times$ Outsider & & & & & $\begin{array}{l}-0.016 \\
(-0.07)\end{array}$ & $\begin{array}{c}0.095 \\
(0.41)\end{array}$ \\
\hline Other controls & Yes & Yes & Yes & Yes & Yes & Yes \\
\hline Adj. $R^{2}$ & $9.22 \%$ & $9.31 \%$ & $15.19 \%$ & $15.29 \%$ & $12.78 \%$ & $12.86 \%$ \\
\hline \multicolumn{7}{|c|}{ Panel C: Controlling for asset tangibility } \\
\hline & $(1)$ & $(2)$ & (3) & (4) & $(5)$ & $(6)$ \\
\hline Short Interest & $\begin{array}{l}-1.400^{a} \\
(-4.14)\end{array}$ & $\begin{array}{l}-1.334^{a} \\
(-3.97)\end{array}$ & & & & \\
\hline Short Interest $\times$ Connectedness & & $\begin{array}{l}-0.386^{a} \\
(-2.92)\end{array}$ & & & & \\
\hline Option/Stock volume & & & $\begin{array}{l}-0.444^{b} \\
(-2.52)\end{array}$ & $\begin{array}{l}-0.391^{b} \\
(-2.06)\end{array}$ & & \\
\hline Option/Stock volume $\times$ Connectedness & & & & $\begin{array}{l}-0.468^{a} \\
(-2.74)\end{array}$ & & \\
\hline Institutional OIB & & & & & $\begin{array}{c}0.124^{a} \\
(4.16)\end{array}$ & $\begin{array}{cc}a & 0.107^{a} \\
& (3.44)\end{array}$ \\
\hline Institutional OIB $\times$ Connectedness & & & & & & $\begin{array}{c}0.093^{b} \\
(1.96)\end{array}$ \\
\hline Connectedness & & $\begin{array}{l}0.338^{a} \\
(3.36)\end{array}$ & & $\begin{array}{l}0.293^{a} \\
(3.47)\end{array}$ & & $\begin{array}{c}-0.015 \\
(-0.54)\end{array}$ \\
\hline Asset Tangibility & $\begin{array}{c}0.144 \\
(0.40)\end{array}$ & $\begin{array}{r}0.277 \\
(0.81)\end{array}$ & $\begin{array}{l}1.136^{c} \\
(1.80)\end{array}$ & $\begin{array}{l}1.258^{b} \\
(2.01)\end{array}$ & $\begin{array}{l}0.434^{a} \\
(3.61)\end{array}$ & $\begin{array}{cc}a & 0.419^{a} \\
& (3.47)\end{array}$ \\
\hline Short Interest $\times$ Asset Tangibility & $\begin{array}{l}1.447^{a} \\
(3.47)\end{array}$ & $\begin{array}{l}1.289^{a} \\
(3.31)\end{array}$ & & & & \\
\hline Option/Stock volume $\times$ Asset Tangibility & & & -0.457 & -0.713 & & \\
\hline Institutional OIB $\times$ Asset Tangibility & & & $(-0.56)$ & $(-0.86)$ & $\begin{array}{l}-0.240^{a} \\
(-2.67)\end{array}$ & $\begin{array}{c}a-0.189^{c} \\
(-1.91)\end{array}$ \\
\hline Other controls & Yes & Yes & Yes & Yes & Yes & Yes \\
\hline Adj. $R^{2}$ & 9.48 & 9.54 & 15.28 & 15.36 & 12.83 & 12.90 \\
\hline
\end{tabular}




\section{Table 9}

\section{Board Connectedness, informed trading and stock returns: Within-firm regressions.}

This table presents the results from firm fixed effects (within-firm) regressions of stock returns on informed trading variables, connectedness, and other firm characteristics. Connectedness is the residual obtained from a regression of the natural logarithm of aggregate connections on the natural logarithm of firm size and board size. The dependent variables are monthly future stock returns in columns (1) and (2), and weekly future stock returns in column (3). The firm characteristics are as defined in Table 1. The sample consists of common stocks listed on AMEX, NASDAQ and NYSE with board data in the BoardEx database from January 2002 to December 2011. Other control variables are identical to those included in Table 5, and are defined in Table 1. Firm and time fixed effects are included in all specifications. $t$-statistics, based on robust standard errors and clustered by firm, are reported in parentheses below the coefficient estimates. Superscripts $a, b$, and $c$ indicate significance at the $1 \%, 5 \%$, and $10 \%$ levels, respectively.

\begin{tabular}{|c|c|c|c|}
\hline & (1) & (2) & (3) \\
\hline Short Interest & $\begin{array}{l}-2.403^{a} \\
(-9.53)\end{array}$ & & \\
\hline Short Interest $\times$ Connectedness & $\begin{array}{l}-0.804^{b} \\
(-2.05)\end{array}$ & & \\
\hline Option/Stock volume & & $\begin{array}{l}-1.107^{a} \\
(-4.28)\end{array}$ & \\
\hline Option/Stock volume $\times$ Connectedness & & $\begin{array}{l}-0.988^{b} \\
(-2.09)\end{array}$ & \\
\hline Institutional OIB & & & $\begin{array}{c}0.066^{b} \\
(2.52)\end{array}$ \\
\hline Institutional OIB $\times$ Connectedness & & & $\begin{array}{c}0.087^{c} \\
(1.79)\end{array}$ \\
\hline Connectedness & $\begin{array}{c}0.415 \\
(1.42)\end{array}$ & $\begin{array}{c}-0.230 \\
(-0.66)\end{array}$ & $\begin{array}{l}-0.080 \\
(-1.23)\end{array}$ \\
\hline Other controls & Yes & Yes & Yes \\
\hline Firm fixed effects & Yes & Yes & Yes \\
\hline Time fixed effects & Month & Month & Week \\
\hline Adj. $R^{2}$ & $23.8 \%$ & $26.7 \%$ & $27.4 \%$ \\
\hline
\end{tabular}


Table 10

Board Connectedness and the probability of adverse selection in trading.

This table presents results pertaining to the relation between changes in proxies for adverse selection in the cost of trading, and changes in Connectedness. The PIN measure is that constructed by Brown and Hillegeist (2007) who extend that developed by Easley et al. (1997). Spread is the difference between ask price and bid price (ask-bid) divided by the mid point of bid and ask spread, averaged over the year to obtain average annual bid ask spread. Illiquidity is as defined in Amihud (2002). Connectedness is the residual obtained from a regression of the natural logarithm of aggregate connections on the natural logarithm of firm size and board size. The sample consists of common stocks listed on AMEX, NASDAQ and NYSE with board data in the BoardEx database from January 2002 to December 2011. In Panel A, firms are sorted into quintiles based on annual mean change in Connectedness, such that $\mathrm{C} 1$ (C5) is the quintile that experienced the least (most) change in Connectedness, and we report the mean change in the adverse selection proxies for each of the quintiles. In Panel B the dependent variable is the annual change in the adverse selection proxies, and the key explanatory variable is annual change in Connectedness ( $\Delta$ Connectedness). Other firm characteristics are as defined in Table 1. Newey-West $t$-statistics, are reported in parentheses. Superscripts $a, b$, and $c$ indicate significance at the $1 \%, 5 \%$, and $10 \%$ levels, respectively.

\begin{tabular}{rrrrrrrrr}
\hline \multicolumn{7}{c}{ Panel A: Change in connectedness and adverse selection proxies: Quintiles } \\
\hline Change in Connectedness quintiles (C) & C1 & C2 & C3 & C4 & C5 & C5 - C1 & $t(\mathrm{C} 5-\mathrm{C} 1)$ \\
\cline { 2 - 9 } & & & & & & \\
Mean Change in Connectedness & -0.239 & -0.059 & 0.015 & 0.096 & 0.332 & & \\
Mean Change in PIN measure & -0.611 & -0.003 & -0.396 & 0.392 & 0.641 & $1.252^{a}$ & $(5.49)$ \\
Mean Change in Spread (\%) & -0.186 & -0.140 & -0.129 & -0.105 & -0.088 & $0.098^{b}$ & $(2.08)$ \\
Mean Change in Illiquidity & -0.013 & -0.005 & 0.004 & 0.005 & 0.037 & $0.051^{a}$ & $(2.70)$ \\
\hline
\end{tabular}

Panel B: Change in connectedness and adverse selection proxies: Multivariate regressions

\begin{tabular}{|c|c|c|c|c|c|c|}
\hline \multirow[b]{2}{*}{$\Delta$ Connectedness } & \multicolumn{2}{|c|}{ Change in PIN } & \multicolumn{2}{|c|}{ Change in Spread } & \multicolumn{2}{|c|}{ Change in Illiquidity } \\
\hline & $\begin{array}{l}0.624^{a} \\
(3.10)\end{array}$ & $\begin{array}{l}0.557^{a} \\
(2.91)\end{array}$ & $\begin{array}{l}0.006^{b} \\
(2.22)\end{array}$ & $\begin{array}{l}0.005^{b} \\
(2.02)\end{array}$ & $\begin{array}{l}0.377^{b} \\
(2.35)\end{array}$ & $\begin{array}{c}0.348^{b} \\
(2.46)\end{array}$ \\
\hline Firm Size & $\begin{array}{l}-0.217 \\
(-0.74)\end{array}$ & $\begin{array}{c}-0.341 \\
(-0.99)\end{array}$ & $\begin{array}{l}0.000 \\
(0.03)\end{array}$ & $\begin{array}{r}0.007 \\
(0.59)\end{array}$ & -0.214 & $\begin{array}{l}-0.571 \\
(-0.88)\end{array}$ \\
\hline Inst. Own. & $\begin{array}{c}0.962 \\
(1.13)\end{array}$ & $\begin{array}{c}1.389 \\
(1.45)\end{array}$ & $\begin{array}{c}0.021 \\
(0.58)\end{array}$ & $\begin{array}{c}0.048 \\
(1.55)\end{array}$ & $\begin{array}{c}2.299 \\
(0.49)\end{array}$ & $\begin{array}{c}2.345 \\
(0.54)\end{array}$ \\
\hline BM & $\begin{array}{c}0.073 \\
(0.74)\end{array}$ & $\begin{array}{c}0.026 \\
(0.35)\end{array}$ & $\begin{array}{l}-0.003 \\
(-0.22)\end{array}$ & $\begin{array}{c}0.003 \\
(0.32)\end{array}$ & $\begin{array}{l}2.092^{b} \\
(2.03)\end{array}$ & $\begin{array}{l}2.723^{c} \\
(1.83)\end{array}$ \\
\hline Turnover & $\begin{array}{l}0.745^{a} \\
(3.19)\end{array}$ & $\begin{array}{l}0.695^{a} \\
(2.66)\end{array}$ & $\begin{array}{c}0.035 \\
(0.91)\end{array}$ & $\begin{array}{l}0.020 \\
(0.56)\end{array}$ & $\begin{array}{l}-2.040 \\
(-0.75)\end{array}$ & $\begin{array}{c}-2.749 \\
(-0.96)\end{array}$ \\
\hline MOM & $\begin{array}{l}-1.160^{a} \\
(-4.36)\end{array}$ & $\begin{array}{l}-1.310^{a} \\
(-3.45)\end{array}$ & $\begin{array}{l}-0.133^{a} \\
(-3.30)\end{array}$ & $\begin{array}{l}-0.133^{a} \\
(-3.46)\end{array}$ & $\begin{array}{l}-0.836 \\
(-0.73)\end{array}$ & $\begin{array}{c}-0.331 \\
(-0.25)\end{array}$ \\
\hline IVOL & $\begin{array}{l}-15.937^{b} \\
(-2.36)\end{array}$ & $\begin{array}{c}-3.404 \\
(-0.51)\end{array}$ & $\begin{array}{c}-0.794 \\
(-0.78)\end{array}$ & $\begin{array}{l}-0.800 \\
(-0.82)\end{array}$ & $\begin{array}{c}44.314 \\
(0.54)\end{array}$ & $\begin{array}{c}73.891 \\
0.71)\end{array}$ \\
\hline Return & & $\begin{array}{l}-2.979^{a} \\
(-6.28)\end{array}$ & & $\begin{array}{l}-0.224^{a} \\
(-4.53)\end{array}$ & & $\begin{array}{c}-12.734^{b} \\
(-2.03)\end{array}$ \\
\hline Firm Age & & $\begin{array}{l}0.472^{b} \\
(2.07)\end{array}$ & & $\begin{array}{l}-0.015 \\
(-1.25)\end{array}$ & & $\begin{array}{c}0.303 \\
(1.26)\end{array}$ \\
\hline Leverage & & $\begin{array}{c}-0.205 \\
(-0.31)\end{array}$ & & $\begin{array}{l}-0.053 \\
(-0.84)\end{array}$ & & $\begin{array}{r}5.325 \\
(1.56)\end{array}$ \\
\hline Number of Analysts & & $\begin{array}{c}0.743 \\
(1.42)\end{array}$ & & $\begin{array}{c}0.008 \\
(1.38)\end{array}$ & & $\begin{array}{l}1.506^{c} \\
(1.82)\end{array}$ \\
\hline R\&D & & $\begin{array}{l}-1.681 \\
(-0.77)\end{array}$ & & $\begin{array}{c}0.056 \\
(0.83)\end{array}$ & & $\begin{array}{c}20.620 \\
(1.32)\end{array}$ \\
\hline Performance & & $\begin{array}{l}-0.908 \\
(-0.58)\end{array}$ & & $\begin{array}{l}-0.103 \\
(-1.62)\end{array}$ & & $\begin{array}{c}5.226 \\
(0.74)\end{array}$ \\
\hline Number of Segments & & $\begin{array}{l}-0.010 \\
(-0.55)\end{array}$ & & $\begin{array}{l}-0.001^{a} \\
(-2.70)\end{array}$ & & $\begin{array}{l}-0.087 \\
(-0.94)\end{array}$ \\
\hline Intercept & $\begin{array}{c}0.524 \\
(0.11)\end{array}$ & $\begin{array}{c}0.543 \\
(0.14)\end{array}$ & $\begin{array}{l}-0.141 \\
(-0.66)\end{array}$ & $\begin{array}{c}-0.163 \\
(-0.81)\end{array}$ & $\begin{array}{c}4.913 \\
(0.30)\end{array}$ & $\begin{array}{c}4.916 \\
(0.37)\end{array}$ \\
\hline Adj. $R^{2}$ & $4.30 \%$ & $4.87 \%$ & $28.09 \%$ & $31.34 \%$ & $13.27 \%$ & $14.77 \%$ \\
\hline
\end{tabular}


Figure 1: Annual quintile hedge portfolio returns for each connectedness tercile. For each of our informed trading values (Short Interest, Option/Stock Volume and Institutional OIB), we divide our firms into three groups based on the magnitude of Connectedness. The figure shows the annualized stock return, for each connectedness tercile, in each year, for the hedge portfolio that is long the firms in the highest quintile of the informed trading variable, and short the firms in the lowest quintile.

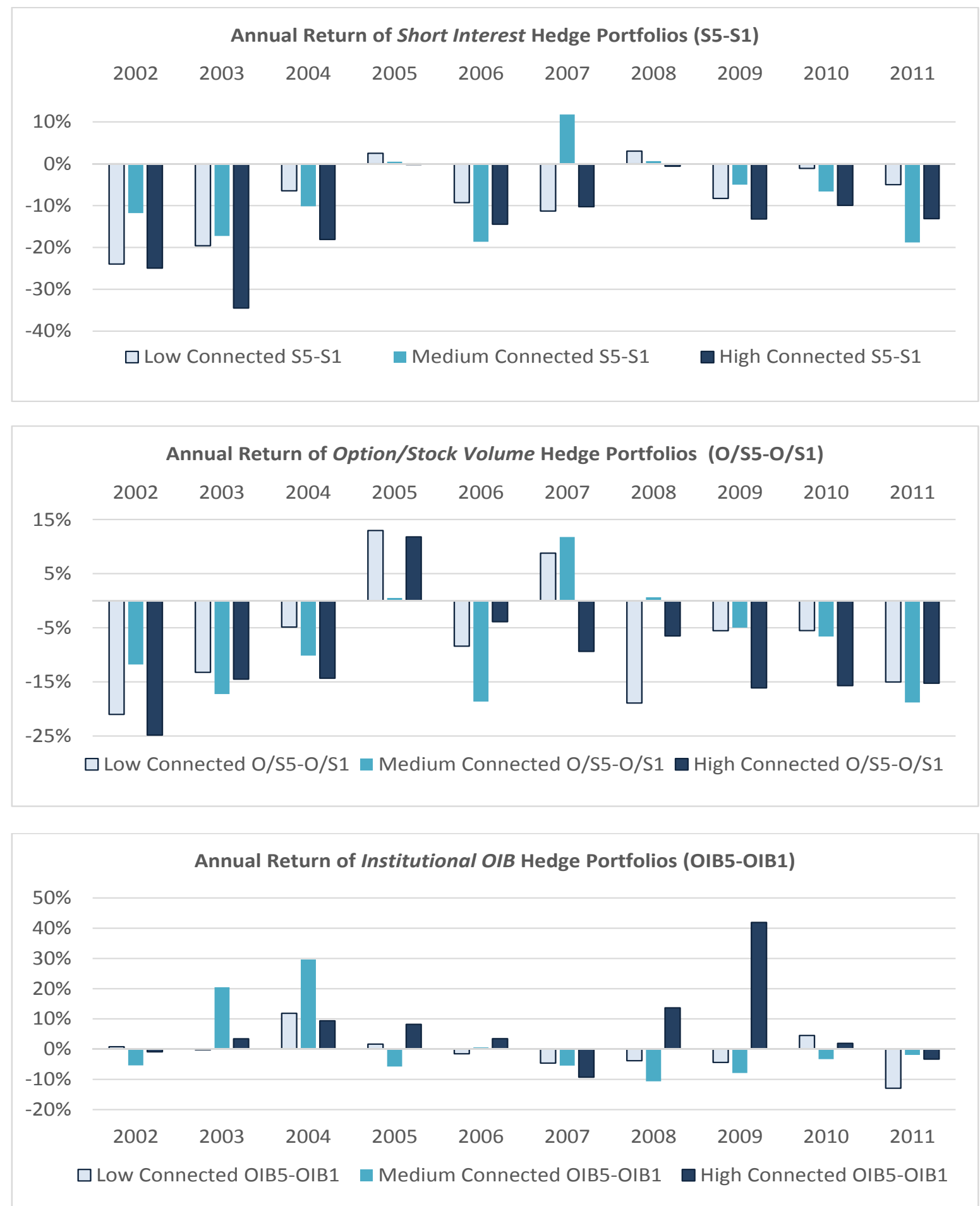


Figure 2. Cumulative abnormal returns scaled by total returns over the sixty day window leading to earnings announcement. Firms are divided deciles based on their earnings surprises such that firms in the first decile have the most negative earning surprises and firms in the tenth decile have the most positive. Figure $2 \mathrm{a}$ shows the returns for firms that report the most negative earnings surprise. Figure $2 b$ shows the returns for firms that report the most positive earnings surprise.

Figure 2a. Bad News

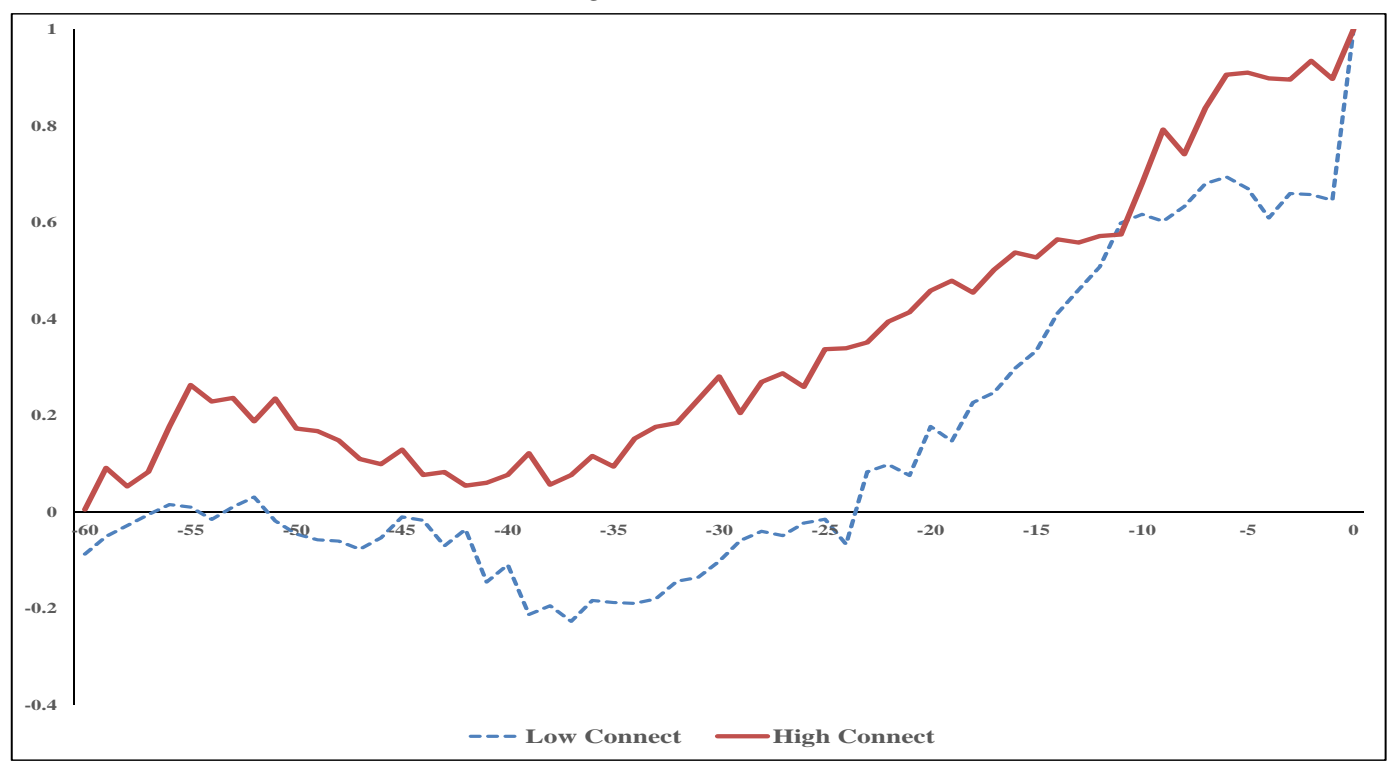

Figure 2b. Good news

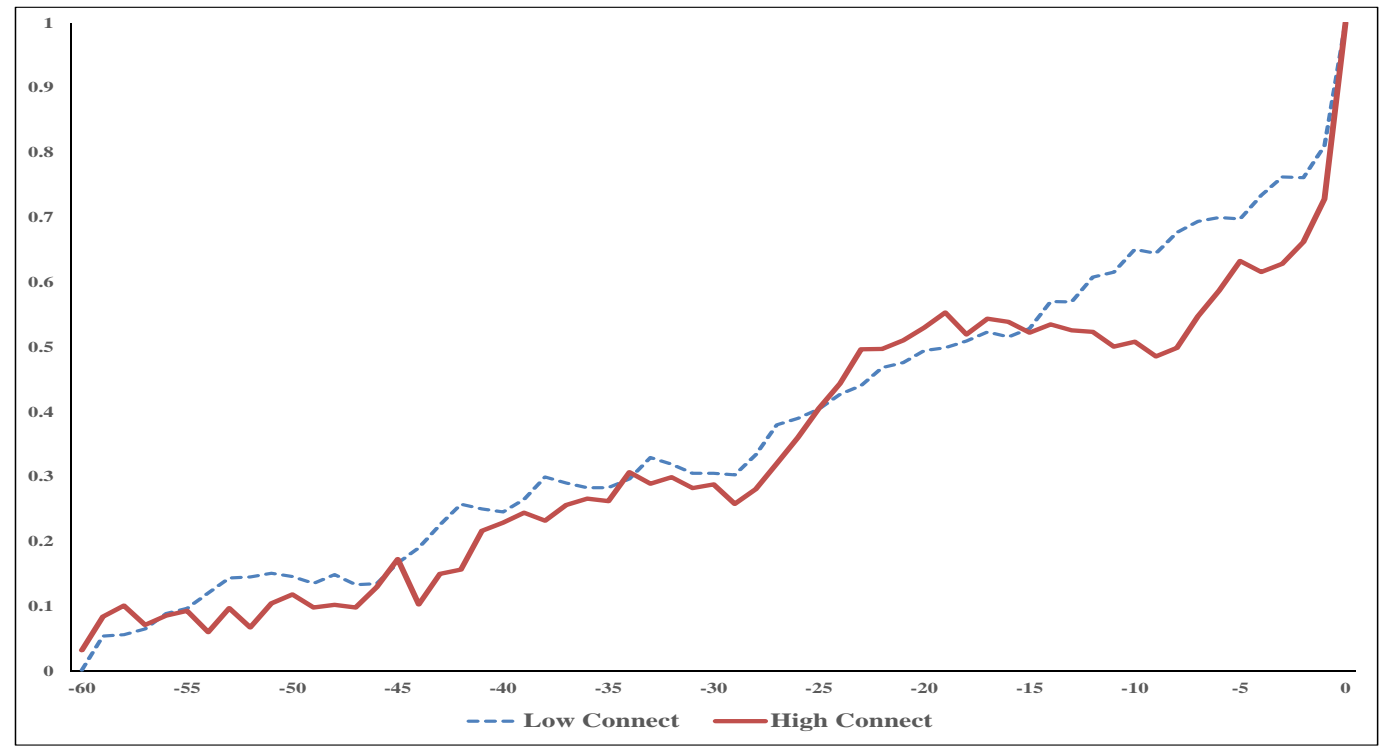

